Cite this: Chem. Soc. Rev., 2012, 41, 5102-5116

\section{Polymer derived non-oxide ceramics modified with late transition metals $\dagger$}

\author{
Muhammad Zaheer, ${ }^{a}$ Thomas Schmalz, ${ }^{b}$ Günter Motz ${ }^{* b}$ and Rhett Kempe ${ }^{* a}$ \\ Received 30th November 2011 \\ DOI: $10.1039 / \mathrm{c} 2 \mathrm{cs} 15326 \mathrm{~b}$
}

This tutorial review highlights the methods for the preparation of metal modified precursor derived ceramics (PDCs) and concentrates on the rare non-oxide systems enhanced with late transition metals. In addition to the main synthetic strategies for modified $\mathrm{SiC}$ and $\mathrm{SiCN}$ ceramics, an overview of the morphologies, structures and compositions of both, ceramic materials and metal (nano) particles, is presented. Potential magnetic and catalytic applications have been discussed for the so manufactured metal containing non-oxide ceramics.

\section{Introduction}

In contrast to the classical manufacturing of ceramic powders at high temperatures the processing of polymer derived

\footnotetext{
${ }^{a}$ Inorganic Chemistry II, University of Bayreuth, Universitätsstr. 30, 95440 Bayreuth, Germany. E-mail: kempe@uni-bayreuth.de;

Fax: + 4992155 2157; Tel: + 49921552541

${ }^{b}$ Ceramic Materials Engineering, University of Bayreuth, Ludwig-Thoma-Str. 36b, 95447 Bayreuth, Germany.

E-mail: guenter.motz@uni-bayreuth.de; Fax: + 4992155 5502; Tel: + 49921555505

$\dagger$ Part of a web theme on the topic of nanomaterials (Deutsche Forschungsgemeinschaft SPP1181/Nanomaterials program). DOI:
} $10.1039 / \mathrm{c} 2 \mathrm{cs} 15326 \mathrm{~b}$ ceramics (PDCs) is a relatively young technology and offers a number of advantages over the conventional way.

By using different educts and different types of reactions the chemical and physical properties of the preceramic polymers (precursors) such as elemental composition, solubility, fusibility and viscosity are adjustable. On the one hand special functional groups enable a further modification of the polymer to produce completely new ceramic materials with high purity and homogenous distribution of the elements. On the other hand they provide for a 3-dimensional cross-linking to an unmeltable polymer (green body), which is the precondition for ceramization. The transformation of the thermoset to the ceramic materials already occurs at relatively low

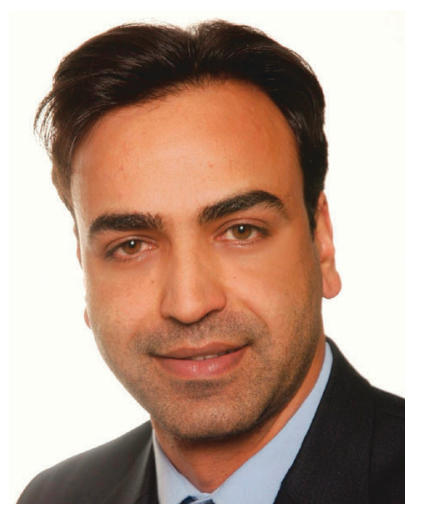

Muhammad Zaheer
Muhammad Zaheer was born in Rawalakot (A.J.K), Pakistan in 1982. He received his bachelor (2002) and master degrees (2005) from The University of Azad Jammu and Kashmir, Muzaffarabad with chemistry as the major subject. His master thesis was focused on the physio-chemical analysis of asphaltum (Silajit). He worked on the synthesis of ferrocene based materials with Prof. Z. Akhter at Quaid-i-Azam University, Islamabad and received his master of philosophy (MPhil) in 2008. Since 2009, he is a PhD student in the group of Prof. R. Kempe at the University of Bayreuth. His current research interests include the synthesis of silicon carbonitride ( $\mathrm{SiCN}$ ) based heterogeneous catalysts and nanomaterials for catalytic applications. He has been awarded university gold medal (MSc UAJK, Muzaffarabad), merit scholarship ( $Q A U$, Islamabad) and HEC/DAAD scholarship. As a boy scout, he was awarded Chief Commissioner's award and Quaid-i-Azam award.

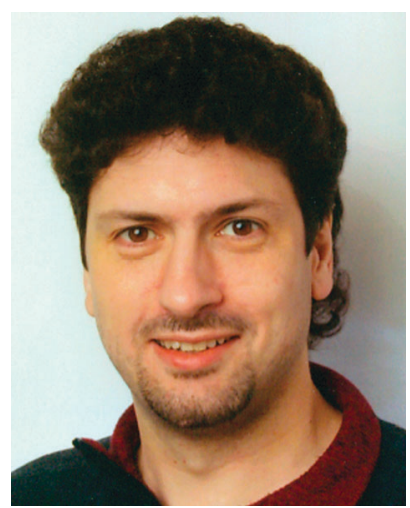

Thomas Schmalz
Thomas Schmalz was born in Kemnath/Stadt, Germany, in 1969. He received his Diploma degree in 1998, after studying chemistry at the University of Bayreuth. In the same year he started his doctoral research, continuing investigations on the coordination behaviour of the olefinic phosphane $P\left(\mathrm{C}_{7} \mathrm{H}_{7}\right)_{3}$ in group 11 metal compounds, under the supervision of Prof. M. Herberhold. After receiving the $P h D$ degree in 2002 he got a postdoctoral research position at the chair of Organic Chemistry (Prof. R. Schobert, Bayreuth) with emphasis to carbene complexes used in organic synthesis. In 2004 he returned to his former institute, Inorganic Chemistry II, now under the supervision of Prof. R. Kempe, working on yttrium catalysts for the olefin polymerization. In 2005 he got a position at the chair of Ceramic Materials Engineering, where his interests are the development of new, especially metal modified polysilazanes, and their transformation into the corresponding ceramics. 
temperatures $\left(<1000{ }^{\circ} \mathrm{C}\right)$. Due to the different properties of the preceramic polymers and of the resulting ceramics, various applications as e.g. ceramic fibres, porous ceramics, polymeric and ceramic coatings and as ceramic matrices are established. Due to these applications in combination with the versatile shaping methods precursors such as polysiloxanes, polysilazanes, polycarbosilazanes, polyborosilazanes and polysilylcarbodiimides are becoming more and more important. Recently published review articles and books summarize the interdisciplinary research devoted to PDCs and guide towards earlier summaries and pioneering work in the field. ${ }^{1-5}$ PDCs, like other technical ceramics, can broadly be categorized into two classes: those having an oxygen moiety (oxide ceramics) and the ones without any oxygen (non-oxide ceramics). The characteristic features of the non-oxide systems include their resistance to crystallisation and the high thermal and chemical stabilities. Wide ranging applications are observed for these materials including high performance coatings, sensors, nanocomposites and fibres. The potential of these and further applications, for instance, in energy technologies and catalysis can be extended by the incorporation of metallic or intermetallic nanoparticles or phases. Late transition metals form metallic particles or phases during pyrolysis due to the reductive conditions in combination with their noble character, and they are highly relevant for catalytic applications. In a more general sense, two of the oldest and very different classes of materials, ceramics and metals, are combined and structured on a nano-scale. In this review we describe and summarize the initial attempts made to synthesis late transition metal modified polymer derived non-oxide ceramics and the applications of these materials.

\section{General strategies for the synthesis of metal modified PDCs}

Synthesis of late transition metal enhanced polymer derived non-oxide ceramics can broadly be divided into three categories:

(i) blending of the precursor with metal or metal oxide powders,

(ii) synthesis from metallopolymers, and

(iii) the chemical modification of precursor polymers using coordination compounds.

In the first approach, preformed metal (or metal oxide) particles are simply blended with the preceramic polymers followed by cross-linking and pyrolysis. This method is limited with the particle sizes of the used metal (oxide) powders. In the second and third approach the desired nanoparticles are built-up, most likely via the formation of clusters, starting from the atomic scale. So well defined metallopolymers, in which the metal atoms are already bonded to the monomer units before polymerisation, can be formed in the first place. The modified polymers are then pyrolyzed to obtain the metal containing ceramic. Finally, in the third approach, coordination compounds (also called (metal) complexes) react with the polymeric preceramic precursors. A metal transfer from the complex to the polymer chain can occur, giving rise to metal modified precursors, which are crosslinked and pyrolyzed, yielding the metal enhanced PDCs. Each of these approaches will be discussed in detail for two classes of polymer derived non-oxide ceramics: $\mathrm{SiC}$ and $\mathrm{SiCN}$. This review also concentrates on the modification using late transition metals, including the elements from groups 8-11 (especially Fe, Co, Ni, $\mathrm{Pd}, \mathrm{Pt}, \mathrm{Cu}, \mathrm{Ag}$ and $\mathrm{Au})$.

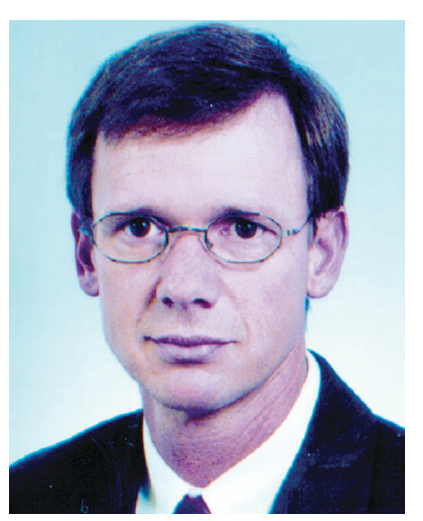

Günter Motz
Günter Motz was born in Diedorf/Eichsfeld, Germany, in 1962. He studied chemistry at the Universität Leipzig and received his Diploma degree in 1989 (EPR investigations on silver particles). In 1990 he started his doctoral research with the focus on synthesis and characterization of preceramic polymers at Universität Stuttgart under the supervision of Prof. G. Becker. After receiving the $P h D$ degree in 1996 he got a postdoctoral research position at the University of Bayreuth (Prof. G. Ziegler) with emphasis to develop polymers in the system SiCN for the manufacturing of ceramic SiCN fibres. Since 1999 he is working as the head of the PDC Group and got a permanent position in 2005 at the chair of Ceramic Materials Engineering. His research interests involve the development of new preceramic polymers, ceramic fibres, coatings and functional ceramics. He is an author of more than 70 publications and patents.

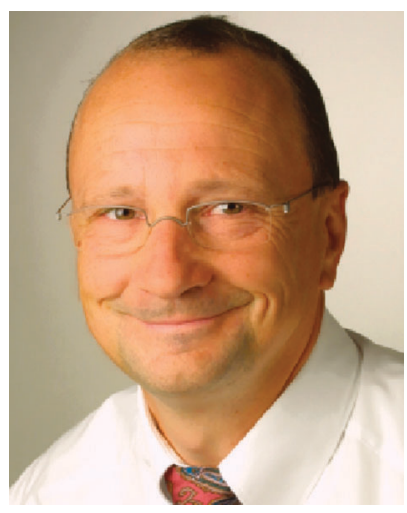

Rhett Kempe
Rhett Kempe was born in Dresden in 1964. He received his PhD degree (organo nickel chemistry) under the supervision of Prof. J. Sieler (1989). During a DAAD post-doctoral research fellow-ship at MIT (1992/1993) with Prof. R. R. Schrock he became interested in $\mathrm{N}_{2}$ activation. After a second postdoc at the MPI für Kohlenforschung in Mülheim (1993/1994) he begun to study for his habilitation in the Max-Planck-Gesellschaft Group "Complex Catalysis" led by Prof. U. Rosenthal. The habilitation (amido metal chemistry) followed in 1998. He worked as a group leader in the Institut für Organische Katalyseforschung in Rostock (IfOK) for two years and then moved as a visiting scientist in 2000/2001 to the University of Melbourne (Prof. R. Robson). He became a Professor of Inorganic Chemistry at the University of Oldenburg in 2001 and was appointed to a Chair of Inorganic Chemistry at the University of Bayreuth in 2002. His research interests are metal-metal bonding and the development of novel catalyst systems. He is an author of more than 330 publications and was awarded, for instance, the Karl-Winnacker-Stipendium and the Heisenberg-Stipendium. 


\section{Metal modified $\mathrm{SiC}$ ceramics $(\mathrm{M} @ \mathrm{SiC})$}

\subsection{Modification by metal (oxide) powders}

In 1976, Yajima et al. $^{6}$ reported the synthesis of polycarbosilane (PCS) followed by its mixing with $\mathrm{Fe}-\mathrm{Cr}$ alloy powder containing $13 \mathrm{wt} \% \mathrm{Cr}$ in the ratio of $1: 9$. After air drying the mixture was hot pressed and heated with a rate of $5 \mathrm{~K} \mathrm{~min}^{-1}$ up to $1100{ }^{\circ} \mathrm{C}$ and kept for $1 / 2$ hour. This resulted in the formation of spherical or ellipsoidal particles of $\mathrm{Cr}_{7} \mathrm{C}_{3}$ and $\mathrm{CrSi}_{2}$. The material was resistant to oxidation and showed hardly any increase in weight after heating at $1000{ }^{\circ} \mathrm{C}$ for 50 hours under air.

More recently, poly[(silylene)diacetylenes] were modified by dispersing metal oxides $\left(\mathrm{Co}_{3} \mathrm{O}_{4}, \mathrm{NiO}, \mathrm{PdO}, \mathrm{PtO}_{2}\right) .{ }^{7}$ Subsequent pyrolysis of the dispersions above $1400{ }^{\circ} \mathrm{C}$ under argon afforded metal silicides (CoSi, $\left.\mathrm{Ni}_{2} \mathrm{Si}, \mathrm{Pd}_{3} \mathrm{Si} / \mathrm{Pd}_{4} \mathrm{Si}, \mathrm{Pt}_{3} \mathrm{Si} / \mathrm{Pt}_{5} \mathrm{Si}\right)$ and graphitic carbon as detected by powder XRD. The metal silicides were formed through the reaction of $\mathrm{SiC}$ with the metal particles with the release of graphitic carbon.

The formation of metal silicides (in the case of $\mathrm{Ni}$ ) from the pyrolysis of mixture of metal powder and polysilane under argon atmosphere was also reported by Seyferth et al. ${ }^{8}$

\subsection{Metal modified $\mathrm{SiC}$ ceramics from metallopolymers}

3.2.1 Iron containing precursors. Ferrocene based metallopolymers were investigated intensively as precursors for ceramic materials by Whittell and Manners. ${ }^{9}$ In 1993 this group reported $^{10}$ the formation of magnetic ceramics from the pyrolysis of poly(ferrocenylsilanes) (PFSs) (Fig. 1, 1 and 2) at $500{ }^{\circ} \mathrm{C}$ under nitrogen atmosphere. High molecular weight PFSs were prepared by the ring-opening polymerization of [1]sila-ferrocenophane precursors.

The ceramic yields were rather low (35-40\%) for 1 and 2 . Ceramics were attracted by bar magnets and powder XRD confirmed their amorphous nature. EDX analysis indicated the presence of iron, silicon and carbon together with trace amounts of oxygen. Poly(ferrosinylsilanes) with $\mathrm{Si}-\mathrm{H}$ - and vinyl-functions (compounds 3 and $\mathbf{4}$ in Fig. 1) gave the highest yields $(60-65 \%)$ at $600{ }^{\circ} \mathrm{C}$ under nitrogen. ${ }^{11}$ Pyrolysis of a $1: 1$ blend of the polymers $\mathbf{3}$ and $\mathbf{4}$ afforded the ceramic in $62 \%$ yield at $600{ }^{\circ} \mathrm{C}$ and the highest ceramic yield at $1000{ }^{\circ} \mathrm{C}$ $(56 \%)$ owing to the efficient cross-linking of the polymer via hydrosilylation. Analysis of the ceramics with SEM and EDX indicated that these materials were iron/silicon carbides. The ceramic formed at $600{ }^{\circ} \mathrm{C}$ was found to be amorphous, whereas the corresponding one formed at $1000{ }^{\circ} \mathrm{C}$ contained $\alpha$-Fe crystallites (by powder XRD). The formation of polymer 1 (Fig. 1) followed by subsequent pyrolysis inside the channels of mesoporous silica produced magnetic ceramic composites. ${ }^{12}$ Data collected from powder XRD, solid-state NMR, DSC,

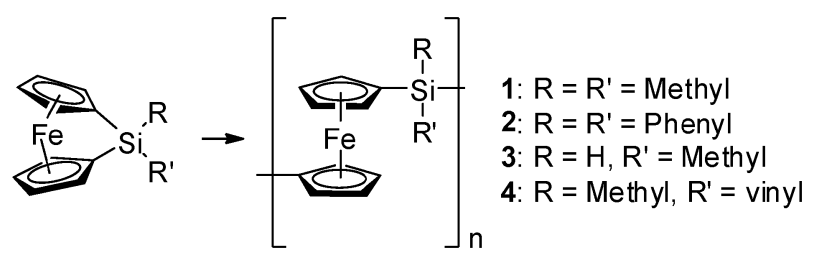

Fig. 1 Synthesis of poly(ferrocenylsilanes) via ring-opening polymerisation.

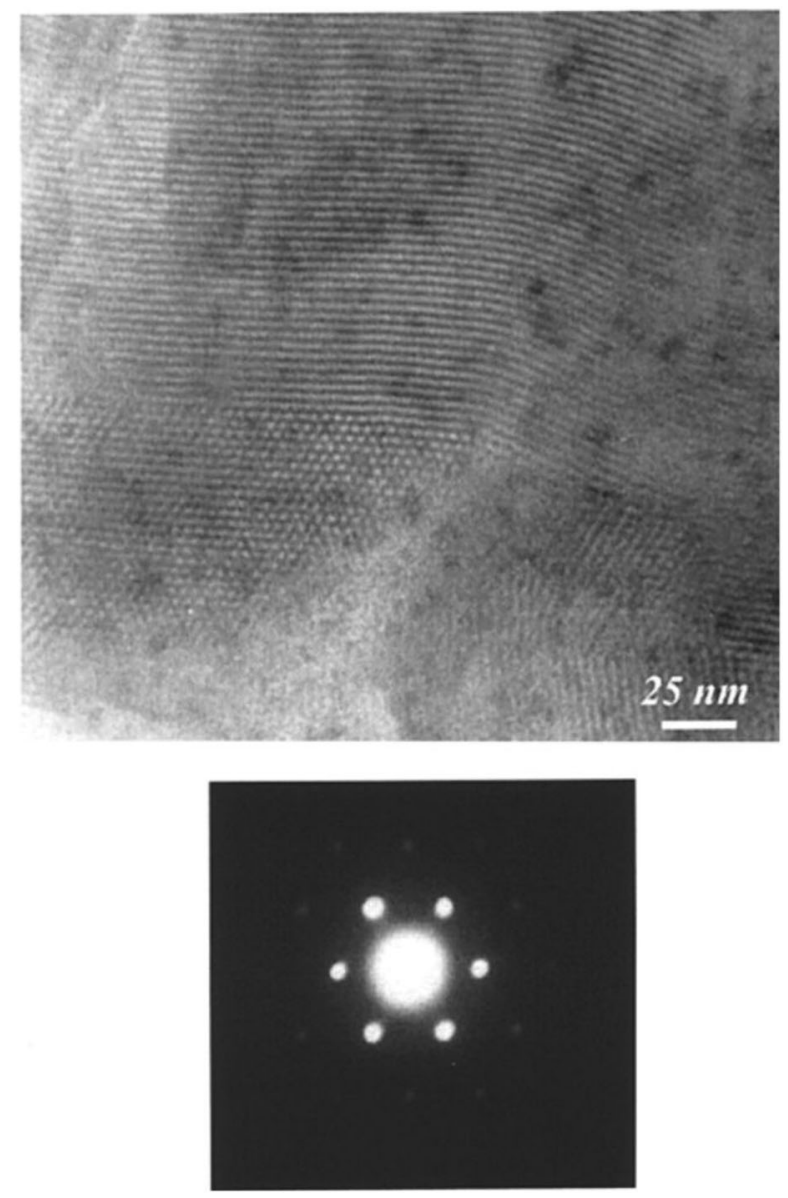

Fig. 2 TEM micrograph of a ceramic-MCM-41 composite (top) with the electron diffraction pattern (bottom) showing the hexagonal order in the ceramics (reproduced from ref. 13 after permission. Copyright 2000 American Chemical Society).

TEM and EDX provided support to the claim that the products of both, polymerization and pyrolysis reactions, remained predominantly inside the channels of the host material. The presence of $\alpha$-Fe nanoparticles with a size of $20 \AA$ was confirmed by powder XRD studies. The product obtained from the pyrolysis of polymer $\mathbf{1}$ in the channels of MCM-41 contained much smaller sized iron than those observed in the pyrolysis of bulk polymer $\mathbf{1}^{13}$ (Fig. 2) The ceramic yield is an important consideration while choosing a suitable ceramic precursor because this ultimately determines the utility, bulk properties and shape retention in the resulting ceramic. Cross-linking the preceramic polymer is a prevalent method for increasing the ceramic yield because it reduces the amount of volatile products.

In 2000, the Manners group ${ }^{14}$ was successful in the synthesis of magnetic ceramics with high yields from highly cross-linked spirocyclic [1] silaferrocenophane (B in Fig. 3). Under nitrogen atmosphere ceramic yield was above $90 \%$ resulting in ceramic containing iron nanoclusters together with $\mathrm{SiC}$ and $\mathrm{Si}_{3} \mathrm{~N}_{4}$ as verified by powder XRD and TEM studies. With the increase in pyrolysis temperature, an increase in the size of the iron particles was confirmed (D and $\mathrm{E}$ in Fig. 3). In a full account, details of the pyrolysis (under nitrogen) of a well characterized cross-linked poly(ferrocenylsilane)network derived from the polymerization of $\mathrm{fcSi}\left(\mathrm{CH}_{2}\right)_{3}$ (see Fig. 3) were disclosed. ${ }^{15}$ 


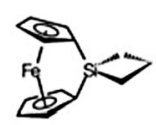

A
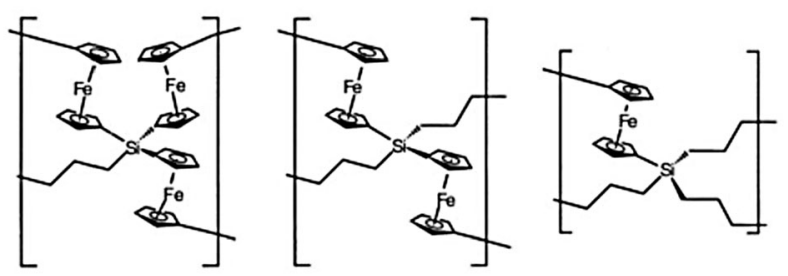

B
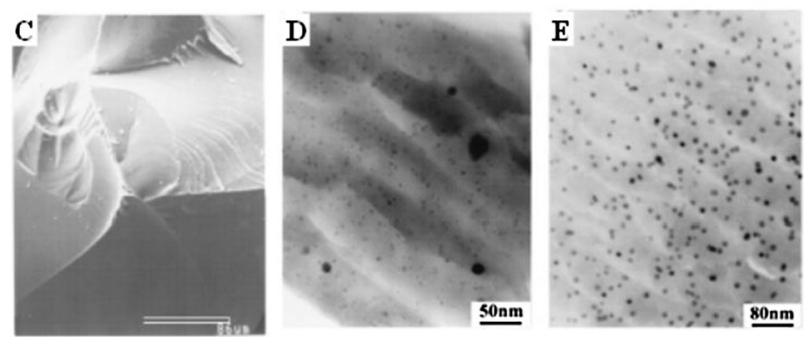

Fig. 3 Spirocyclic [1]silaferrocenophane (A), its polymerization product (B). SEM (C) and TEM micrographs of bulk ceramic obtained by the pyrolysis of $\mathrm{B}$ at $600{ }^{\circ} \mathrm{C}$ (D) and $550{ }^{\circ} \mathrm{C}$ (E) (reproduced from ref. 14 after permission. Copyright 2000 Science, AAAS).
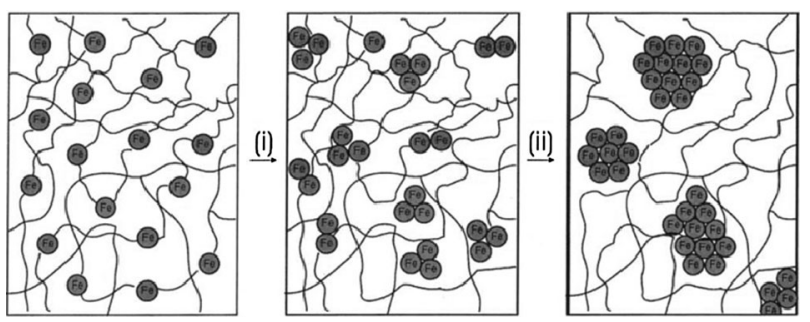

Fig. 4 Graphical representation of a nucleation and growth model that illustrates the genesis of the magnetic ceramic from (i) iron atom release from a polymer (see Fig. 3A) followed by (ii) nucleation and growth of iron nanoparticles (reprinted after permission from ref. 15. Copyright 2009 American Chemical Society).

Variation of both, pyrolysis temperature and holding time, permitted control over the nucleation and growth of the $\alpha$-Fe particles, which ranged in size from around 15 to $700 \AA$. Also the crystallization of the surrounding matrix could be influenced by these parameters (Fig. 4).

The ceramics contained smaller $\alpha$-Fe particles when prepared at temperatures lower than $900{ }^{\circ} \mathrm{C}$ and displayed superparamagnetic behaviour, whereas the materials prepared at $1000{ }^{\circ} \mathrm{C}$ contained larger particles and were ferromagnetic. In addition, the composition of the ceramic was altered by changing the pyrolysis atmosphere to argon, which yielded ceramics that contain $\mathrm{Fe}_{3} \mathrm{Si}_{5}$.

Pyrolysis of hyperbranched poly[1,1-ferrocenylene(methyl)silyne] provided magnetic ceramics. ${ }^{16}$ Sintering at high temperatures $\left(1000-1200{ }^{\circ} \mathrm{C}\right)$ under nitrogen and argon generated ceramics in $48-62 \%$ yields. Hyperbranched polymers were found superior, in terms of the ceramic yield, to the linear ones as ceramic precursors. The ceramics were electrically conductive and possessed a porous architecture constructed of interconnected nanoclusters. The iron content was estimated by EDX to be $36-43 \%$, much higher than that $(11 \%)$ of the ceramic prepared from the linear precursor. The nanocrystals in the ceramics were mainly $\alpha-\mathrm{Fe}_{2} \mathrm{O}_{3}$ and $\mathrm{Fe}_{3} \mathrm{Si}$. Using porous anodic alumina rods as hard template, magnetic ceramic nanorods were synthesized by the polymerization of silaferrocenophanes within the pores. The pyrolysis of the composite at $900{ }^{\circ} \mathrm{C}$ under nitrogen followed by the chemical etching (with $1 \%$ $\mathrm{NaOH})$ provided iron oxide $\left(\mathrm{Fe}_{2} \mathrm{O}_{3}\right)$ containing magnetic ceramic nanorods (NRs). ${ }^{17}$ Highly ordered magnetic ceramic NR arrays were synthesised similarly from poly(ferrocenylsilane) by nanoimprint lithography with anodic aluminium oxide templates. ${ }^{18}$ The key to the method was the controlled infiltration of the precursor in the nanochannels. The resulting ceramic nanorods could precisely replicate the size and shape of their PFS precursor nanorods in the template (Fig. 5).

Inverted opal structures were synthesized using a template consisting of a 3-dimensional arrangement of silica spheres. The ferrocenyl monomers were infiltrated into the void spaces within the silica sphere template. The polymerization at $250{ }^{\circ} \mathrm{C}$ under nitrogen provided polymer silica composites which were etched with aqueous hydrogen fluoride (HF) solution and pyrolyzed (600 and $900{ }^{\circ} \mathrm{C}$ for 6 hours) under nitrogen. Ceramic yield was found to be in the range of $70-85 \%$ and $\mathrm{Fe}_{2} \mathrm{O}_{3}$ nanoparticles were uniformly distributed over the composite. ${ }^{19}$ Iron containing $\mathrm{SiC}(\mathrm{O})$ magnetoceramics were recently synthesized using iron nitrate and a polycarbosilane. ${ }^{20}$ The Fe $@$ PCS precursors were pyrolyzed at $600-1200{ }^{\circ} \mathrm{C}$ to produce magnetoceramics. The powder XRD and TEM analysis showed that the ceramics contained $\mathrm{Fe}_{3} \mathrm{Si}$ nanoparticles, which were dispersed in a amorphous $\mathrm{SiC}(\mathrm{O})$ matrix. Moreover, the crystallization of $\beta-\mathrm{SiC}$ was observed at $1200^{\circ} \mathrm{C}$. Very recently, thermolysis of poly(ferrocenylsilane) at $1000{ }^{\circ} \mathrm{C}$ or poly[\{(dimethylsilyl)-ferrocenyl $\}$ diacetylene $]$ at $850{ }^{\circ} \mathrm{C}$ was reported. ${ }^{21}$ The formation of ferromagnetic $\mathrm{Fe}_{3} \mathrm{Si}$ nanoparticles, well distributed in a $\mathrm{SiC} / \mathrm{C}$ matrix, was observed.

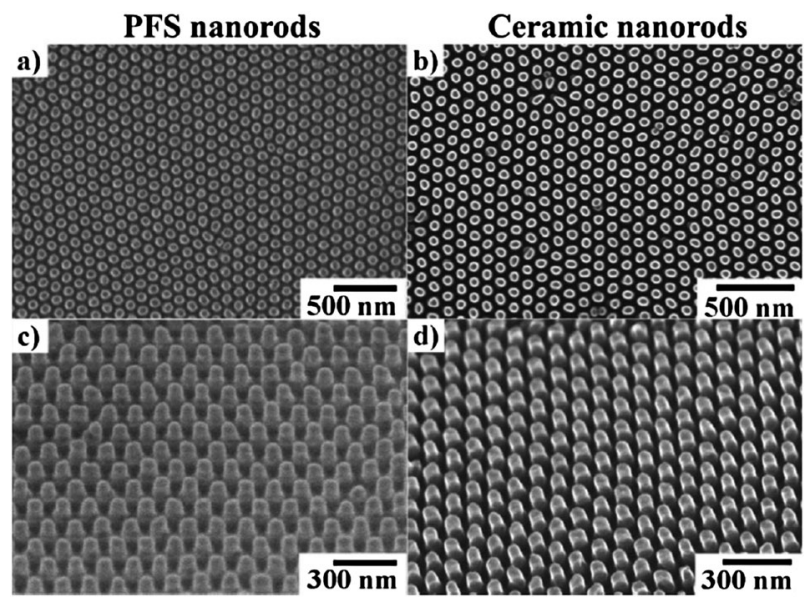

Fig. 5 Large area highly ordered arrays of PFS NRs and their consequent ceramic NRs prepared by pyrolysis at $700{ }^{\circ} \mathrm{C}$ for $5 \mathrm{~h}$ : (a, b) SEM top view- and (c, d) angle view-micrographs (modified and reproduced from ref. 18 after permission. Copyright 2009 American Chemical Society). 
The average size of the formed nanoparticles, their size distribution and their agglomeration behaviour depend strongly on the choice of polymer and the thermolysis conditions.

3.2.2 $\mathrm{Fe} @ \mathrm{SiC}$ ceramics from nanostructured block copolymers. Block copolymers can be self-assembled into a variety of nanoscale morphologies as a result of immiscibility between the constituent blocks. If the structuring of the system can be maintained during pyrolysis nanostructured ceramic materials are possible. The blockcopolymer BC1 (Fig. 6) forms stable cylindrical micelles in $n$-hexane. ${ }^{22}$ These well-characterized micelles can be used to form oriented nanoscopic ceramic lines by hydrogen plasma treatment. ${ }^{23}$ Shell cross-linking of the cylindrical micelles was achieved for BC2 (Fig. 6) by Pt-catalyzed hydrosilylation.

The presence of a cross-linked corona was found to permit the pyrolysis-induced formation of cylindrical ceramic replicas with shape retention up to $600{ }^{\circ} \mathrm{C} .{ }^{24}$ Furthermore, these micelles were deposited on a $\mathrm{Si}$ substrate from solution and upon etching continuous ceramic nanolines with lengths of micrometre and widths of as small as $8 \mathrm{~nm}$ were created. The presence of iron was confirmed by X-ray photoelectron spectroscopy (XPS). ${ }^{25}$ The pyrolysis of cylinder-forming samples of the diblock copolymer PS- $b$-PFEMS in bulk and in thin films produced semi-ordered arrays of $\mathrm{C} / \mathrm{SiC}$ ceramics containing Fe nanoparticles (Fig. 7).

The pyrolysis of thin films stabilized by cross-linking the PS domains with UV light demonstrated high areal yields, improved shape retention, and the presence of cylinder-centered magnetic nanoparticles. ${ }^{26}$

$\mathrm{Pt}(0)$-catalyzed ring-opening precipitation copolymerization of $\mathrm{fcSiMe}_{2}$ (see 1 in Fig. 6) and $\mathrm{fcSi}\left(\mathrm{CH}_{2}\right)_{3}$ (see Fig. 3A) was used to prepare polymer microspheres under mild conditions. Their pyrolysis led to spherical magnetic ceramic replicas (Fig. 8). ${ }^{27}$

Thin films of PS- $b$-PFS were synthesized by spin coating on a silicon wafer and were subjected to UV radiation to cross-link
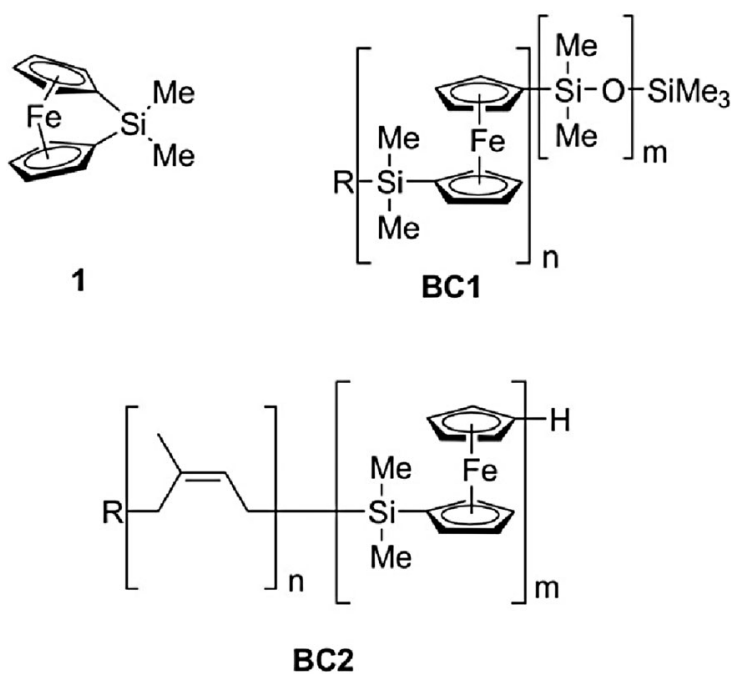

Fig. 6 Structural formulas of [1]silaferrocenophane (1) and block copolymers synthesized from it, poly(ferrocenyldimethylsilane$b$-dimethylsiloxane) (BC1) and poly(isoprene- $b$-ferrocenyl-dimethylsilane) (BC2) $(\mathrm{R}=$ alkyl).

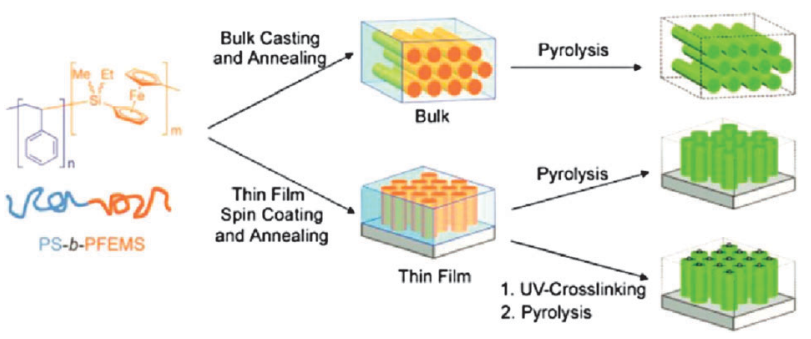

Fig. 7 Generation of ceramic materials from the pyrolysis of bulk samples (top) and thin films (below) of polystyrene-block-poly(ferrocenylethylmethylsilane) (PS-b-PFEMS) (reprinted from ref. 26 after permission. Copyright 2008 American Chemical Society).
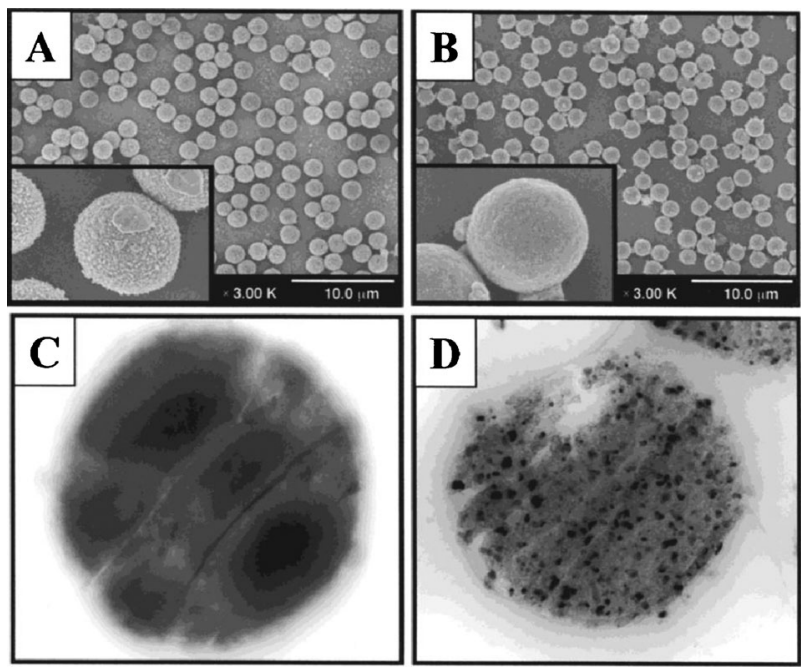

Fig. 8 SEM and thin-section TEM micrographs of ceramic particles obtained from pyrolysis of organometallic microspheres under a nitrogen atmosphere for $(\mathrm{A}, \mathrm{C}) 2 \mathrm{~h}$ at $600{ }^{\circ} \mathrm{C}$ and $(\mathrm{B}, \mathrm{D}) 2 \mathrm{~h}$ at $900{ }^{\circ} \mathrm{C}$ (reprinted after permission from ref. 27. Copyright 2002 American Chemical Society).

the PS matrix. Subsequent pyrolysis $\left(600{ }^{\circ} \mathrm{C}, 2\right.$ hours $)$ resulted in the formation of ceramic nanodots on the surface of the silicon wafer with a repeating space of $40 \mathrm{~nm}$. The XPS studies revealed the presence of $\mathrm{Fe}_{2} \mathrm{O}_{3}$ and $\mathrm{Fe}_{3} \mathrm{O}_{4}$ species. The cylindrical morphology of the block copolymer is lost upon pyrolysis which may be attributed to the lack of the cross-linking of PFS block. The inefficient cross-linking leads to the loss of volatile products during the pyrolysis which in turn destroys the structure. The low yield of the ceramics $(30 \%)$ also supports the inefficient cross-linking. ${ }^{28}$

3.2.3 Bimetallic systems (FeM $@$ SiC ceramics). Sila[1]ferrocenophanes having acetylenic substituents were polymerized and reacted with $\mathrm{Co}_{2}(\mathrm{CO})_{8}$ to get a bimetallic polymer (polymer 2 in Fig. 9). In a typical reaction $75-100 \%$ acetylenic moieties are substituted with cobalt carbonyl. The bimetallic polymer is stable in air and moisture. ${ }^{29}$ The ceramic yield was $72 \%$ and $59 \%$ at 600 and $900{ }^{\circ} \mathrm{C}$, respectively. The black ceramic obtained was attracted by a bar magnet. Powder XRD confirmed the amorphous $\mathrm{SiC} / \mathrm{C}$ and TEM with EDX shows the presence of $\mathrm{Fe}$ and $\mathrm{Co}$ within the same nanoparticle ((d) and (e) in Fig. 9).

A similar approach was used to synthesize ordered 2D arrays of ferromagnetic $\mathrm{Fe} / \mathrm{Co}$ alloy nanoparticle rings with diameters 


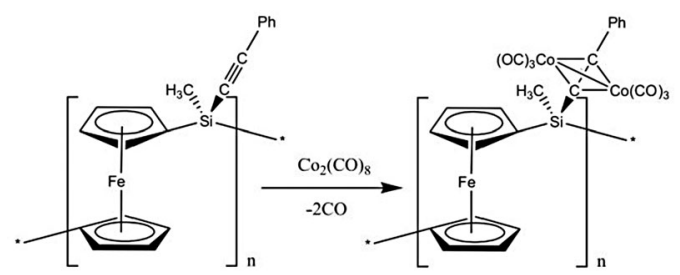

1

2

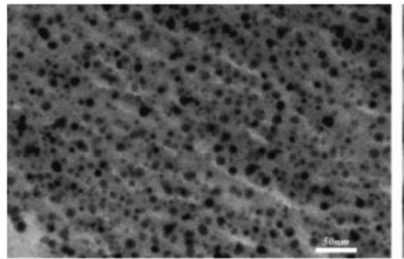

(a)

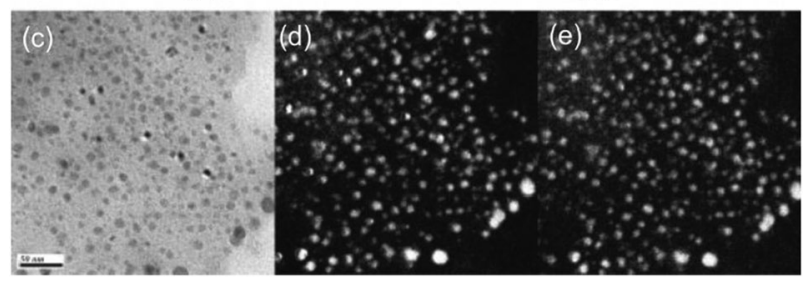

Fig. 9 Synthesis of cobalt modified poly(ferrocenylsilane) (2) from acetylene substituted poly(ferrocenylsilane) (1). TEM images of cross sections of ceramics pyrolyzed at (a) $600{ }^{\circ} \mathrm{C}$ and (b) $900{ }^{\circ} \mathrm{C}$. TEM micrographs of ceramic cross section (c) with the corresponding EDS maps for (d) iron and (e) cobalt (reprinted after permission from ref. 29. Copyright 2003 Wiley-VCH Verlag GmbH \& Co.).

of $2-12 \mu \mathrm{m} .{ }^{30}$ The highly metallized poly(ferrocenylsilane) precursors were structured via template directed self-assembly followed by plasma etching and pyrolysis. Furthermore, thin films (Fig. 10) were made of Co@PFS whose pyrolysis afforded patterned ferromagnetic ceramics with excellent shape retention. ${ }^{31-33}$

Solution processing is a facile method to generate magnetic thin films. Poly(ferrocenylethylmethylsilane) (PFEMS, Fig. 11A) was doped with Pd using two methods: sublimation of $\left[\mathrm{Pd}(\mathrm{acac})_{2}\right](\mathrm{acac}=$ acetylacetonate $)$ to form $\mathrm{Pd}$ nanoparticles in the polymer films and direct mixing of $\left[\mathrm{Pd}(\mathrm{acac})_{2}\right]$ with the polymer precursor prior to film deposition. Pyrolysis of the precursors yielded ferromagnetic ceramics (Fig. 11B-D). The effect of the pyrolysis temperature and atmosphere on the magnetic properties, chemical composition, and crystalline structure of the ceramics was explored. For the ceramics derived from pyrolysis $\left(1000{ }^{\circ} \mathrm{C}\right.$, under argon) of Pd@PFEMS, the formation of $\mathrm{Fe} / \mathrm{Pd}$ alloys was observed. All the samples show characteristic reflection patterns of $\mathrm{Fe}_{3} \mathrm{O}_{4}$ and $\mathrm{Fe}_{2} \mathrm{O}_{3}$ suggesting an incorporation of oxygen during their handling and storage. $^{34}$

3.2.4 Other M@SiC ceramics. Ferrocene is a very stable and easy to modify organometallic molecule, and thus ideal to incorporate into metallopolymers. Unfortunately, this chemistry is restricted to iron, but also for other late transition metals strategies to incorporate these elements into non-oxide ceramics have to be developed.
Following the aforementioned protocol, synthesis and pyrolysis of a series of nickel containing polycarbosilanes (Ni@PCS, Fig. 12) was described. ${ }^{35}$

Pyrolysis of the Ni@PCSs yielded ceramics with embedded $\mathrm{Ni}$ or $\mathrm{Ni}$ silicide nanoparticles. By adjusting the pyrolysis temperature, it was possible to control the formation of either nickel $\left(400\right.$ and $600{ }^{\circ} \mathrm{C}$ ) or nickel silicide $\left(\mathrm{Ni}_{3} \mathrm{Si}\right.$ and $\left.\mathrm{Ni}_{31} \mathrm{Si}_{12}\right)$ nanoparticles $\left(900{ }^{\circ} \mathrm{C}\right.$ ) (see TEM micrographs in Fig. 12). The substituent group (phenyl or $t$-butyl), the clusterization percentage and the pyrolysis time, all influenced the yield and properties of ceramic materials.

The pyrolysis of poly[\{(diorganosilylene)diacetylene $\}$ dicobalthexacarbonyls] (Fig. 13) at $1350{ }^{\circ} \mathrm{C}$ gave $\mathrm{Co}_{2} \mathrm{Si}$ and graphite-like carbon. Evolution of part of the carbon monoxide in the early stage of the pyrolysis $\left(100{ }^{\circ} \mathrm{C}\right)$ showed that the cross-linking of the diacetylene units was induced by reactive cobalt species. Furthermore, at higher temperatures $\left(200-500{ }^{\circ} \mathrm{C}\right)$, cobalt clusters catalyze the formation of the ceramic. $\mathrm{Co}_{2} \mathrm{Si}$ was shown to result from the reaction of $\mathrm{SiC}$ with $\mathrm{Co}$ above $1000{ }^{\circ} \mathrm{C}$, both formed during the pyrolysis process. Finally, at $1100{ }^{\circ} \mathrm{C}$, a carboreduction reaction led to the elimination of the oxygen incorporated in the carbon matrix during the crosslinking process. ${ }^{36}$

Furthermore, porous $\mathrm{CeO}_{2} / \mathrm{Pt}$-polycarbosilane composites, using an aqueous hexachloroplatinic acid as a hydrosilylation catalyst causing cross-linking of allyl groups in the liquid PCS, were reported. ${ }^{37}$ The cross-linked polymers showed high specific surface areas and well dispersed ceria nanoparticles in the matrix. Pyrolysis at $1200-1500{ }^{\circ} \mathrm{C}$ and post-oxidative treatment at various temperatures produce porous ceramic structures with surface areas up to $423 \mathrm{~m}^{2} \mathrm{~g}^{-1}$. X-Ray diffraction investigations showed that the crystallinity of the $\mathrm{SiC}$ matrix could be controlled by the pyrolysis temperature.

\subsection{Modification by coordination compounds}

First investigations on reactions between precursor polymers and coordination compounds were reported by Seyferth and coworkers. ${ }^{38}$ The presence of $\mathrm{Si}-\mathrm{H}$ - and $\mathrm{Si}-\mathrm{Si}$-functions in Nicalon polycarbosilane (PCS) provided an opportunity to add polynuclear transition metal carbonyls $\left(\mathrm{Ru}_{3}(\mathrm{CO})_{12}\right.$, $\left.\mathrm{Fe}_{3}(\mathrm{CO})_{12}, \mathrm{Os}_{3}(\mathrm{CO})_{12}, \mathrm{Rh}_{6}(\mathrm{CO})_{16}, \mathrm{Co}_{4}(\mathrm{CO})_{12}, \mathrm{Co}_{2}(\mathrm{CO})_{8}\right)$ to the polymer backbone. ${ }^{39}$ Their addition resulted in the desired cross-linking of the polycarbosilane and provided an increased ceramic yield. For instance, the addition of $2 \mathrm{wt} \%$ of $\mathrm{Ru}_{3}(\mathrm{CO})_{12}$ to PCS provided a ceramic yield of $76 \%$ at $1000{ }^{\circ} \mathrm{C}$ under argon atmosphere. The chemical composition of the pyrolysis product at $1500{ }^{\circ} \mathrm{C}$ was found to be $88.8 \% \mathrm{SiC}$ and $11.1 \%$ C. However no details about the fate and behaviour of the metals inside the resulting ceramics were reported.

The pyrolysis of an iron containing polycarbosilane $\left(1300{ }^{\circ} \mathrm{C} / \mathrm{Ar}\right)$ was used to synthesize magnetic SiC nanowires. ${ }^{40}$ Therefore poly(dimethylsilane) was simply mixed with $\left[\mathrm{Fe}(\mathrm{acac})_{3}\right](\mathrm{acac}=$ acetylacetonate). The powder XRD spectrum of the material showed the presence of typical diffraction lines of a $\beta$-SiC crystal along with diffraction lines related to $\mathrm{Fe}_{5} \mathrm{Si}_{3}$, $\mathrm{Fe}_{3} \mathrm{Si}$ and $\mathrm{FeC}$. Similarly, the formation of silicon carbide $(\mathrm{SiC})$ fibers using an iron containing polycarbosilane was reported. ${ }^{41}$ Iron pentacarbonyl $\left[\mathrm{Fe}(\mathrm{CO})_{5}\right]$ was first reacted with PCS. Nanosized $\alpha$-Fe domains rather uniformly distributed were 
Temp. I: Film surface morphology

$300^{\circ} \mathrm{C}$

No NPs observed

$400{ }^{\circ} \mathrm{C}$

$$
\text { No NPs observed }
$$

$500^{\circ} \mathrm{C}$
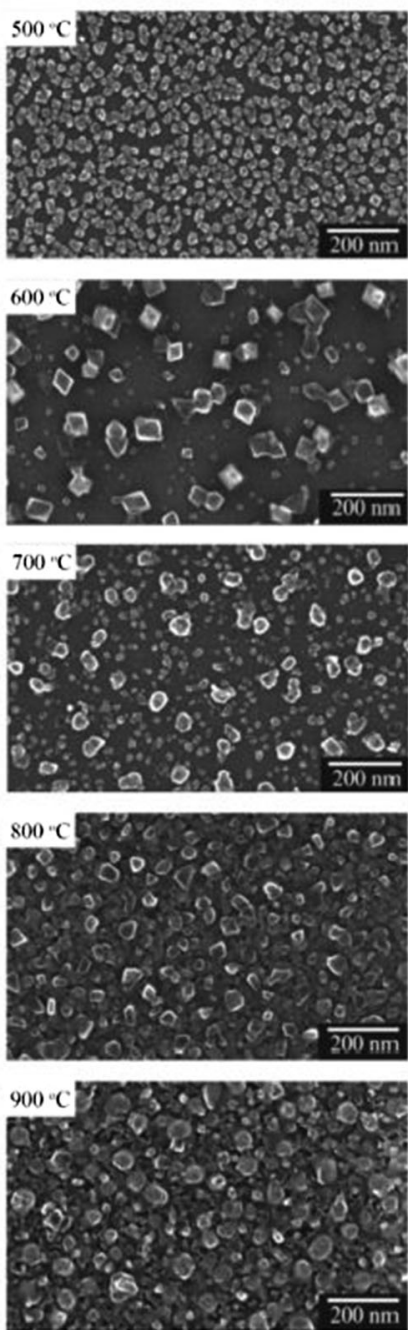

II: Surface NP size distribution

No NPs observed

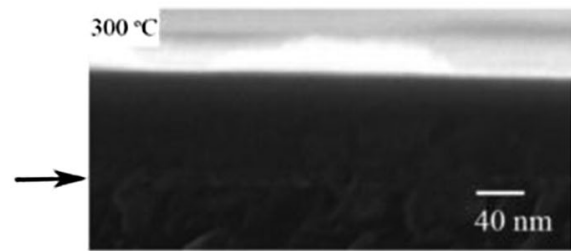

$400^{\circ} \mathrm{C}$
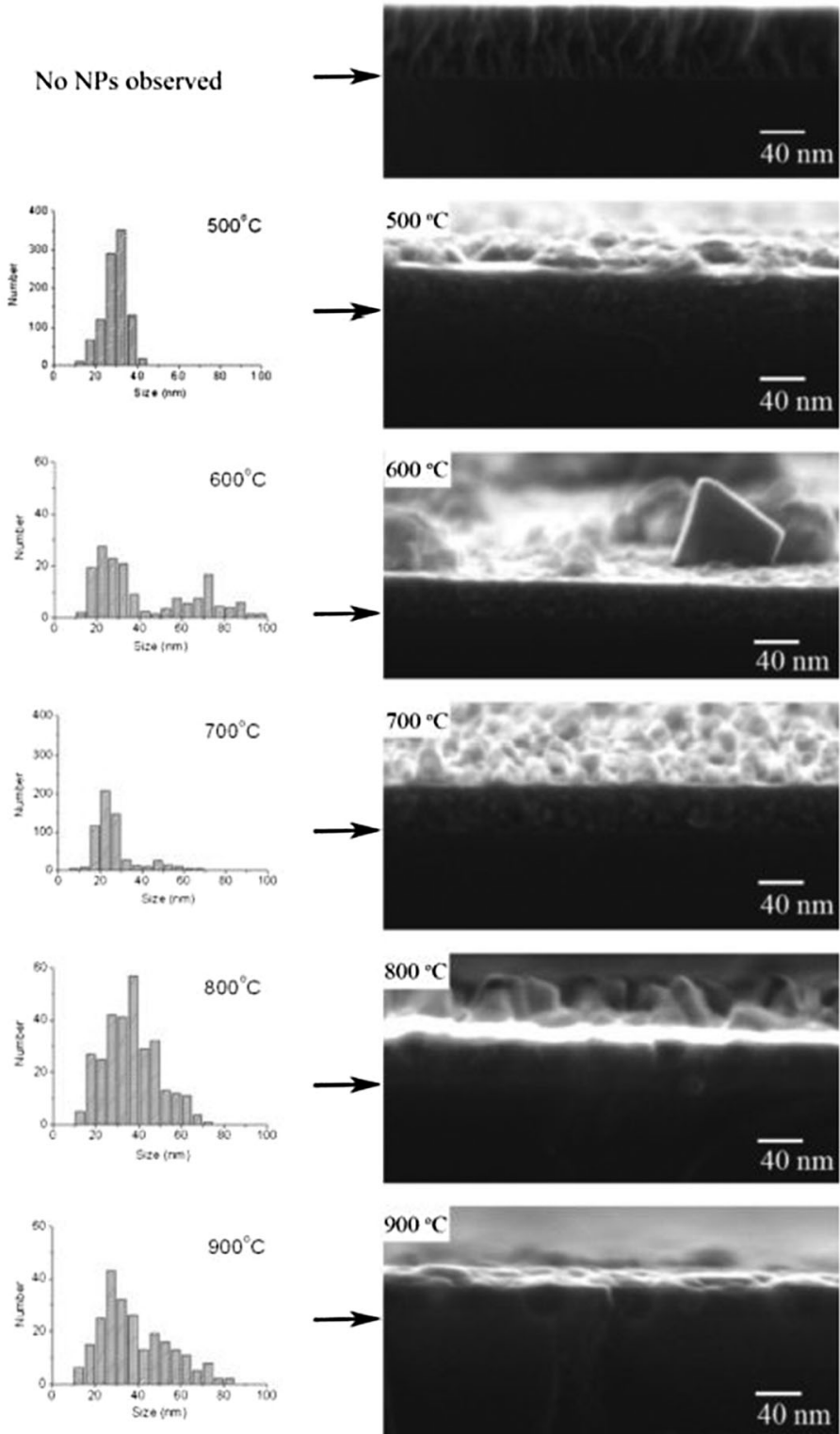

Fig. 10 Vertical view SEM micrographs (series I), surface particle size distributions (series II), and cross-sectional SEM micrographs (series III) for Co@PFS thin films pyrolyzed at 300, 400, 500, 600, 700, 800 and $900{ }^{\circ} \mathrm{C}$. The original film thickness before pyrolysis was about $200 \mathrm{~nm}$. The arrows in series III indicate the interface of the Si substrate and the pyrolyzed film (reprinted after permission from ref. 33 . Copyright 2006 American Chemical Society).

found inside the ceramic fibres. The formation of $\mathrm{Si}_{3} \mathrm{~N}_{4}$ and $\mathrm{SiC}$ nanowires using an iron $\left(\mathrm{FeCl}_{2}\right)^{42}$ or a cobalt compound $\left(\mathrm{CoCl}_{2}\right)^{43}$ and poly(methyl-phenylsilsesquioxane) was described. Powder XRD analysis of the iron samples pyrolyzed at $1250{ }^{\circ} \mathrm{C}$ under nitrogen flow showed the crystallization of $\beta-\mathrm{SiC}, \alpha-\mathrm{Si}_{3} \mathrm{~N}_{4}$, $\mathrm{Fe}_{3} \mathrm{Si}$ and $\mathrm{Si}_{2} \mathrm{ON}_{2}$. Moreover at $1350{ }^{\circ} \mathrm{C}$, the formation of single crystalline $\mathrm{Si}_{3} \mathrm{~N}_{4}$ nanowires took place. In the case when samples were pyrolyzed at $1400{ }^{\circ} \mathrm{C}$ under argon atmosphere, $\mathrm{SiC}$ nanowires with spherical tips (iron silicide) were generated as confirmed by HR-TEM coupled EELS and EDX measurements. Powder XRD studies showed the presence of $\beta-\mathrm{SiC}, \mathrm{Fe}_{3} \mathrm{Si}$ and amorphous carbon as major phases present in the samples 


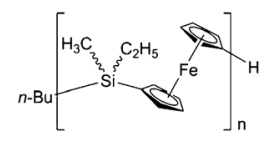

$\mathbf{A}$

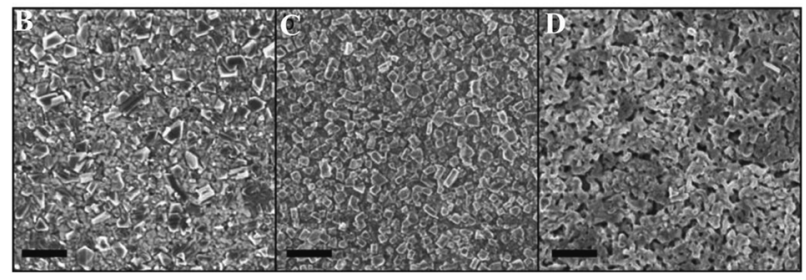

Fig. 11 Structural formula of poly(ferrocenylethylmethylsilane) (PFEMS, A) with SEM micrographs of the ceramics obtained from the pyrolysis of PFEMS (B), PFEMS containing Pd nanoparticles (C) and PFEMS containing $\mathrm{Pd}(\mathrm{acac})_{2}$ pyrolyzed under argon stream at $1000{ }^{\circ} \mathrm{C}(\mathrm{D})$. (Scale bar: $1 \mu \mathrm{m}$ ) (reprinted after permission from ref. 34. Copyright 2011 American Institute of Physics).
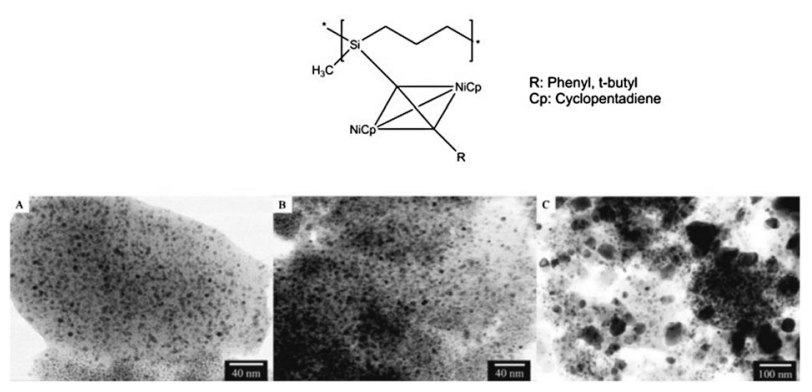

Fig. 12 Structural formula of nickel containing poly(ferrocenylsilane) (Ni@PFS) along with the TEM images of pyrolyzed ceramics at (A) 400, (B) 600, and (C) $900{ }^{\circ} \mathrm{C}$ for $1 \mathrm{~h}$ (reproduced after permission from ref. 35 . Copyright 2007 American Chemical Society).

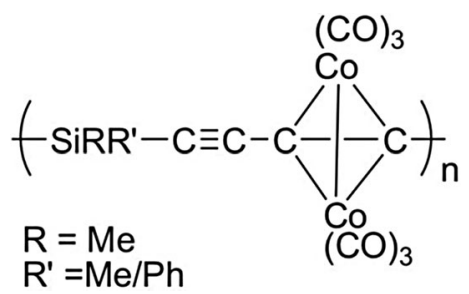

Fig. 13 Structural formula of poly[\{(diorganosilylene)diacetylene $\}$ dicobalthexacarbonyls].

pyrolyzed at $1250-1300{ }^{\circ} \mathrm{C}$ under argon atmosphere. Authors obtained the similar results using $\mathrm{CoCl}_{2}$ assisted pyrolysis of the precursor. The resulting ceramics containing nanowires showed a specific surface area up to $110 \mathrm{~m}^{2} \mathrm{~g}^{-1}$.

\section{Metal modified SiCN ceramics $(\mathrm{M} @ \mathrm{SiCN})$}

\subsection{Modification by metal (oxide) powders}

One of the first examples on the modification of PSZs with metal (oxide) powders for the synthesis of metal containing $\mathrm{SiCN}$ ceramics was reported in $2003 .{ }^{44}$ The composites were synthesized by mixing of $\mathrm{Fe}_{3} \mathrm{O}_{4}$ powder with a liquid PSZ, followed by pyrolysis at different temperatures. Investigations of the products by powder XRD revealed that above $600{ }^{\circ} \mathrm{C}$ only the diffraction peaks for $\mathrm{Fe}_{3} \mathrm{O}_{4}$ could be found. At $700{ }^{\circ} \mathrm{C}$, $\mathrm{Fe}_{3} \mathrm{O}_{4}$ begins to reduce to $\alpha-\mathrm{Fe}$, accompanied by the formation of iron-silicate. This reaction is complete at $1000{ }^{\circ} \mathrm{C}$. At temperatures above $1100{ }^{\circ} \mathrm{C}, \alpha-\mathrm{Fe}$ begins to convert to $\mathrm{FeN}$.

In 2007, the synthesis of metal enhanced $\mathrm{SiCN}$ ceramics by the mixing of metal powders with a commercial PSZ (Ceraset ${ }^{\circledR}$, Kion Inc., USA) was reported. ${ }^{45,46}$ The PSZ was first thermally cross-linked by heating up to $280{ }^{\circ} \mathrm{C}$ under an argon atmosphere followed by milling. The green body powders were mixed with metal powders ( $\mathrm{Fe}, \mathrm{Co}$ and $\mathrm{Ni}$ ), homogenized with milling, warm pressed and pyrolyzed at $1000{ }^{\circ} \mathrm{C}$ under an argon atmosphere. Phase evolution of the ceramics was carried out by powder XRD. Whereas Ni and Fe form silicides, cobalt exists solely in the metallic phase. The same strategy was applied to mixed metal systems. In these cases, formation of ternary metal silicides was observed.

The formation of nickel silicides was also observed by others. ${ }^{47}$ Nickel powder was mixed with PSZ (Ceraset ${ }^{\mathbb{R}}$ ) to obtain $10 \mathrm{vol} \%$ metal fractions in the resulting metal-ceramic composite. This composite slurry was cross-linked, warm pressed in a graphite die and pyrolyzed at $1000{ }^{\circ} \mathrm{C}$ under nitrogen atmosphere, followed by heat treatment at $1200{ }^{\circ} \mathrm{C}$ for 1 and 10 hours. The powder XRD data from the composite annealed for $1 \mathrm{~h}$ at $1200{ }^{\circ} \mathrm{C}$ in argon show the evolution of crystalline $\mathrm{Ni}_{2} \mathrm{Si}$ and also the presence of metallic $\mathrm{Ni}$. As the annealing time is increased, the peaks corresponding to $\mathrm{Ni}_{2} \mathrm{Si}$ increased in strength while the $\mathrm{Ni}$ peaks subsided. After annealing for $10 \mathrm{~h}$, a new phase, corresponding to $\mathrm{Si}_{3} \mathrm{~N}_{4}$, was found. Similar observations were made in the SiCN ceramics synthesized by the mixing of $\mathrm{Fe}$ and $\mathrm{Co}$ with PSZ $\left(\right.$ Ceraset $\left.{ }^{\mathbb{R}}\right) .{ }^{48}$ The formation of $\mathrm{Fe}_{3} \mathrm{Si}$ and $\mathrm{Co}_{2} \mathrm{Si}$ was confirmed by quantitative powder XRD analysis. In a different publication the same authors investigated the crystallization behaviour of iron containing $\mathrm{SiCN}$ ceramics at temperatures well above $1000{ }^{\circ} \mathrm{C} .{ }^{49}$ The synthesis of a $\mathrm{Fe}_{3} \mathrm{Si} / \mathrm{SiCN}$ composite was accomplished via pyrolysis at $1100{ }^{\circ} \mathrm{C}$ in an argon stream. At $1300{ }^{\circ} \mathrm{C}$, the crystalline phases $\mathrm{Fe}_{3} \mathrm{Si}, \mathrm{Fe}_{5} \mathrm{Si}_{3}$, and $\mathrm{SiC}$ were observed. The crystallization of $\mathrm{SiC}$ was assumed to occur from the liquid $\mathrm{Fe} / \mathrm{Si} / \mathrm{C}$ alloy being formed during the molten state of silicides at $1300{ }^{\circ} \mathrm{C}$.

The group of $\mathrm{Kroke}^{50}$ used a different approach and synthesized silver nanoparticles containing $\mathrm{SiCN}$ ceramics by the mixing of $3 \mathrm{wt} \%$ as-synthesized $\mathrm{Ag}$ nanoparticles with Ceraset ${ }^{\mathbb{R}}$ followed by pyrolysis under flowing nitrogen and/or ammonia. Bulk samples as well as coatings were investigated. Powder X-ray diffraction (XRD), transmission electron microscopy (TEM), thermal analysis (TGA, DTA), absorption spectroscopy (UV-vis) and infrared (IR) spectroscopy were used to characterize the products. At temperatures in the range of $800-1000{ }^{\circ} \mathrm{C}$ silver particles with an average size of 5-7 nm were observed.

\subsection{Metal modified SiCN ceramics from metallopolymers}

Like in the case of PCSs, again iron containing polymers were the first successful attempts in this field. So poly(ferrocenylsilazanes) with linear or linear-cyclic structure were synthesised via hydrosilylation, a reaction during which no by-product is formed. ${ }^{51}$ The ceramic yields of these metallopolymers were estimated by thermogravimetric analysis (TGA) and bulk pyrolysis, 


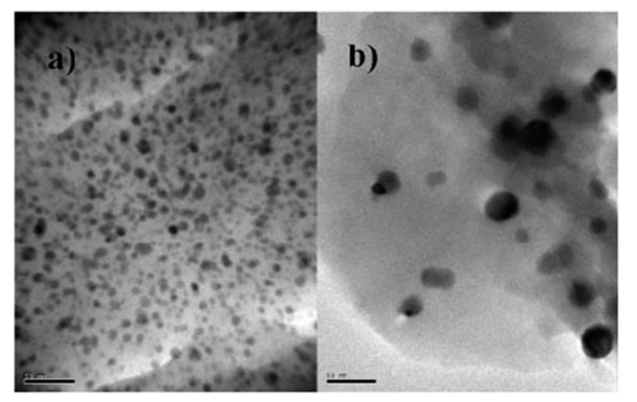

Fig. 14 TEM micrographs of the samples prepared at (a) $500{ }^{\circ} \mathrm{C}$ and (b) $900{ }^{\circ} \mathrm{C}$ (scale bar: $50 \mathrm{~nm}$ ) (reproduced after permission from ref. 52. Copyright 2007 Wiley Periodicals, Inc.).

and were found to depend on the molecular structures. Compared with that of their linear counterparts the ceramic yields of linear-cyclic polymers were much higher.

The preparation of iron-containing PSZs by mixing of $\mathrm{Fe}\left[\mathrm{N}\left(\mathrm{SiMe}_{2} \mathrm{Vi}\right)_{2}\right]_{3}\left(\mathrm{Vi}=-\mathrm{CH}=\mathrm{CH}_{2}\right)$ and a vinyl group containing PSZ afforded magnetic ceramics after cross-linking at $350{ }^{\circ} \mathrm{C}$ (no peroxide addition) and pyrolysis in $\mathrm{N}_{2}{ }^{52}$ (Fig. 14)

The ceramics produced were investigated by $\mathrm{X}$-ray diffraction, transmission electron microscope and vibrating sample magnetometer at room temperature. It was indicated that $\alpha$-Fe is the only magnetic crystalline iron phase embedded in the amorphous $\mathrm{SiCN}$ matrix from 500 to $900{ }^{\circ} \mathrm{C}$. Iron particle size increases with an increase of the pyrolysis temperature (Fig. 14).

The synthesis of silazane and silazane-iron polymers was also performed in an improved configuration of plasma assisted chemical vapor deposition coupled with chemical transport reaction. ${ }^{53}$ The resulted (nano-structured) polymers were then pyrolyzed at $1200{ }^{\circ} \mathrm{C}$ under nitrogen atmosphere. Evidence for the presence of $\mathrm{Fe}_{3} \mathrm{C}$ and $\mathrm{Si}_{3} \mathrm{~N}_{4}$ in the pyrolysis products of the iron containing polymer is presented. Hexamethyldisilazane and ferrocene/ hexamethyldisilazane were used as molecular precursors, respectively. ${ }^{54,55}$

\subsection{Modification by coordination compounds}

Among the many polysilazanes (PSZs) available, especially those containing vinyl- and $\mathrm{Si}-\mathrm{H}$ functionalities are widely used for the fabrication of $\mathrm{SiCN}$ ceramics since they show a very good cross-linking behaviour resulting in good ceramic yields. Additionally, the availability of reactive $\mathrm{N}-\mathrm{H}-$, vinyl- and $\mathrm{Si}-\mathrm{H}$-functionalities in these precursors allows the incorporation of metal atoms into the polymer chains. So covalent bonds between the metal ions and the polysilazanes can be established by the reaction with coordination compounds. During these metal transfer the ligand of the coordination compound is released and after cross-linking may become a part of the preceramic polymer. Polymer-metal binding is essential in the regard that it avoids the loss of metal via sublimation during pyrolysis. This molecular approach is advantageous, owing to the dispersion of the metal at an atomic level, the broad applicability (coordination compounds of many metals can be used) and the use of rather inexpensive (commercially available) polymer precursors.

A metal containing $\mathrm{SiCN}$ ceramic was synthesized by reacting lithiated polysilazanes with $\mathrm{FeCl}_{3}$ followed by pyrolysis under argon, nitrogen and ammonia. ${ }^{56}$ Ceramic yields were found to be higher than in the case of the unmodified silazanes. Powder XRD of the ceramics pyrolyzed under argon and nitrogen showed crystalline $\mathrm{Fe}$ while those heated under ammonia showed $\mathrm{Fe}_{4} \mathrm{~N}, \mathrm{Fe}_{3} \mathrm{~N}$ and Fe. One drawback of this approach is the difficulty of removing unreacted $\mathrm{FeCl}_{3}$ and formed $\mathrm{LiCl}$ completely because of their poor solubility in organic solvents. Also along the investigation of PSZ cross-linking reactions induced by iron chloride addition, ${ }^{57}$ some $\mathrm{Fe} @ \mathrm{SiCN}$ ceramics were detected. The cross-linked solids were pyrolyzed at 500-1000 ${ }^{\circ} \mathrm{C}$ under nitrogen atmosphere after curing at $130{ }^{\circ} \mathrm{C}$ for 24 hours. A ceramic yield of $80 \%$ at $800{ }^{\circ} \mathrm{C}$ was observed. Powder XRD measurements at $500{ }^{\circ} \mathrm{C}$ showed the presence of crystalline iron along with the $\mathrm{NH}_{4} \mathrm{Cl}$ and $\mathrm{Fe}_{3} \mathrm{C}$ while at $1000{ }^{\circ} \mathrm{C}$ the crystallization of $\mathrm{Si}_{3} \mathrm{~N}_{4}$ and $\mathrm{Fe}_{3} \mathrm{Si}$ was observed. The crystallization of $\mathrm{Si}_{3} \mathrm{~N}_{4}$ at a temperature of about $900{ }^{\circ} \mathrm{C}$ is quite unusual. Electron paramagnetic resonance (EPR) and ferromagnetic resonance (FMR) studies of $\mathrm{SiCN}$ ceramics doped with iron revealed a variety of iron species. ${ }^{58}$ Different oxygen containing iron complexes were dissolved in a liquid PSZ followed by cross-linking at $160{ }^{\circ} \mathrm{C}$ (DCP addition) and pyrolysis in the temperature range of $600-1600{ }^{\circ} \mathrm{C}$ for these studies. After pyrolysis between $950-1150{ }^{\circ} \mathrm{C}$, nanocrystalline particles in the ferromagnetic state and $\mathrm{Fe}$ ions incorporated into the free-carbon in the superparamagnetic state were found. Powder XRD studies of the samples show the crystallization of $\mathrm{Si}_{3} \mathrm{~N}_{4}$ above $1300{ }^{\circ} \mathrm{C}$ while at $1100{ }^{\circ} \mathrm{C}$ the existence of $\mathrm{Fe}_{5} \mathrm{Si}_{3}$ and graphitic carbon was confirmed.

In this approach the use of metal carbonyls can be advantageous in the sense that they can initiate hydrosilylation and dehydrocoupling reactions (even at room temperature as shown in the case of $\left.\left[\mathrm{Co}_{2}(\mathrm{CO})_{8}\right]\right)$ leading to the simultaneous cross-linking and metal modification of the polymer. ${ }^{48}$ The formation of intermetallic compounds $\mathrm{Fe}_{3} \mathrm{Si}$ and $\mathrm{Co}_{2} \mathrm{Si}$ was confirmed by XRD and TEM studies using $\mathrm{Fe}$ and Co carbonyls.

The chemical modification of HTT1800 by the use of a $\mathrm{Ni}(\mathrm{II})$ complex resulted in the formation of nanoporous silicon oxycarbo-nitride ceramics modified by Ni nanoparticles. ${ }^{59}$ The as-obtained Ni modified PSZ precursors were thermolyzed at $700{ }^{\circ} \mathrm{C}$ and transformed into ceramic nanocomposites, manifesting a nanoporous structure, revealing a BET surface area of $215 \mathrm{~m}^{2} \mathrm{~g}^{-1}$.

Recently, a molecular approach ${ }^{60}$ for the modification of the PSZ HTT1800 making the use of aminopyridinato metal complexes $^{61,62}$ was developed (Fig. 15).

Amido complexes can be synthesized in good yields on a large scale and are soluble in common organic solvents, so a good polymer/coordination compound mixing is possible. Moreover, they contain the same elements as contained by the precursor polymer, thus avoiding the entry of any alien element into the ceramic composites. The amido ligand contributes towards ceramic yield by providing $\mathrm{Si}, \mathrm{C}$ and $\mathrm{N}$ atoms to the ceramic. Furthermore, nearly all transition metals are addressable. ${ }^{63}$ On the account of the availability of more coordination sites within the PSZ backbone and the intrinsic reactivity of the complex, the metal transfer (here copper) from the complex to the polymer takes place. As a result of this transfer, the liberation of a protonated ligand was observed. The ${ }^{1} \mathrm{H}$ and ${ }^{13} \mathrm{C}$ NMR studies of the reaction between the copper aminopyridinato complex (see Fig. 15 for its structure) and the used 


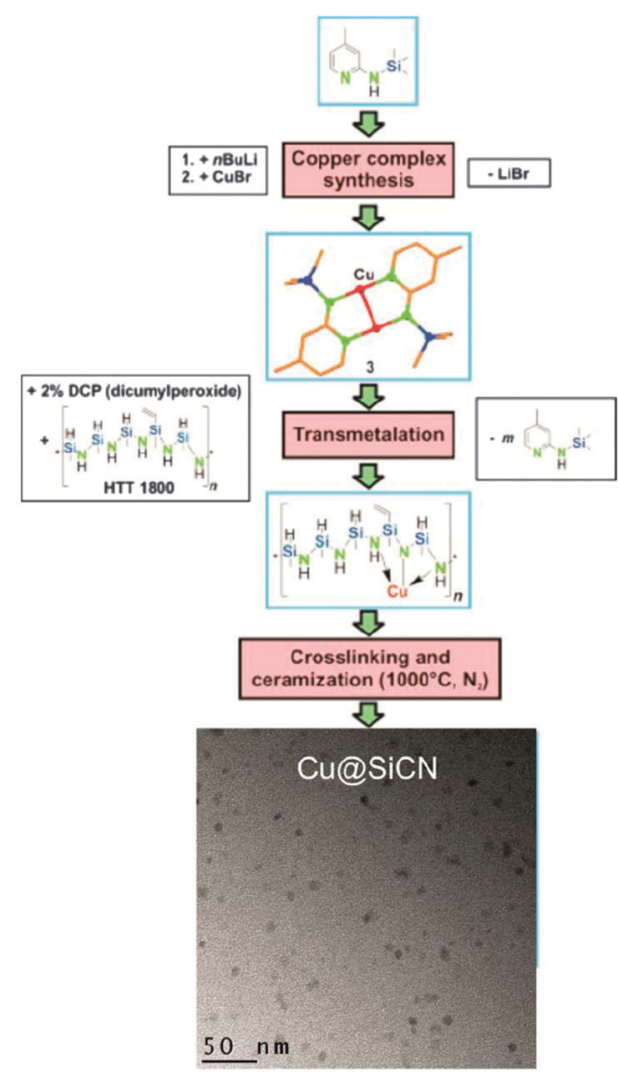

Fig. 15 The approach to $\mathrm{Cu} @ \mathrm{SiCN}$ precursor ceramics via modification by coordination compounds: 4-methyl- $N$-(trimethylsilyl)pyridin-2-amine $\left(\mathrm{Ap}^{\mathrm{TMS}} \mathrm{H}\right)$ is deprotonated with butyl lithium $\left({ }^{n} \mathrm{BuLi}\right)$ and subsequently reacted with $\mathrm{CuBr}$ to yield the copper aminopyridinato complex $\left[\mathrm{Cu}_{2} \mathrm{Ap}_{2}{ }^{\mathrm{TMS}}\right]$. This coordination compound undergoes a metal transfer reaction with the PSZ, here HTT1800, with the release of $\mathrm{Ap}^{\mathrm{TMS}} \mathrm{H}$. After cross-linking with dicumylperoxide (DCP) at $120{ }^{\circ} \mathrm{C}$ the preceramic green body is formed. Pyrolysis affords an amorphous SiCN ceramic enhanced by $\mathrm{Cu}$ nanoparticles $(\mathrm{Cu} @ \mathrm{SiCN})$. For the catalytic applications of $\mathrm{Cu} @ \mathrm{SiCN}$ in alkane oxidation reactions using air as an oxidant please see chapter 5.2 (reproduced after permission from ref. 60. Copyright 2010 Wiley-VCH Verlag GmbH \& Co. KGaA, Weinheim).

PSZ showed the liberation of protonated ligand $\mathrm{Ap}^{\mathrm{TMS}} \mathrm{H}$ providing indirect evidence of the transfer of the metal to the nitrogen functions of the polymer (Fig. 16). The copper transfer was additionally supported by a model reaction, the reaction of $\left[\mathrm{Cu}_{2} \mathrm{Ap}_{2}{ }^{\mathrm{TMS}}\right]$ with an excess of $\mathrm{HN}\left(\mathrm{SiMe}_{3}\right)_{2}(\mathrm{Me}=$ methyl $)$ simulating the polymer backbone. In this reaction the formation of a tetrameric $\mathrm{Cu}$ silylamide was observed. A metal modified polymer was cross-linked using DCP and pyrolyzed at $1000{ }^{\circ} \mathrm{C}$ to form copper containing $\mathrm{SiCN}(\mathrm{Cu} @ \mathrm{SiCN})$. The copper cations bound to the polymer backbone are reduced to a copper metal during the pyrolysis step as observed by solidstate ${ }^{65} \mathrm{Cu}$ NMR spectroscopy, SEM micrographs and energy dispersive spectroscopy (EDS). Furthermore, powder diffraction experiments verified the presence of crystalline copper.

The loading of copper could be varied over a large range up to a $\mathrm{Si}$ to $\mathrm{Cu}$ ratio of 5 . The size of the $\mathrm{Cu}$ particles found in $\mathrm{Cu} @ \mathrm{SiCN}$ increases with a higher loading of copper complex (Fig. 17). Owing to the availability of aminopyridinato complexes, the aforementioned bottom-up approach should be extendable to other (nearly all) transition metals.

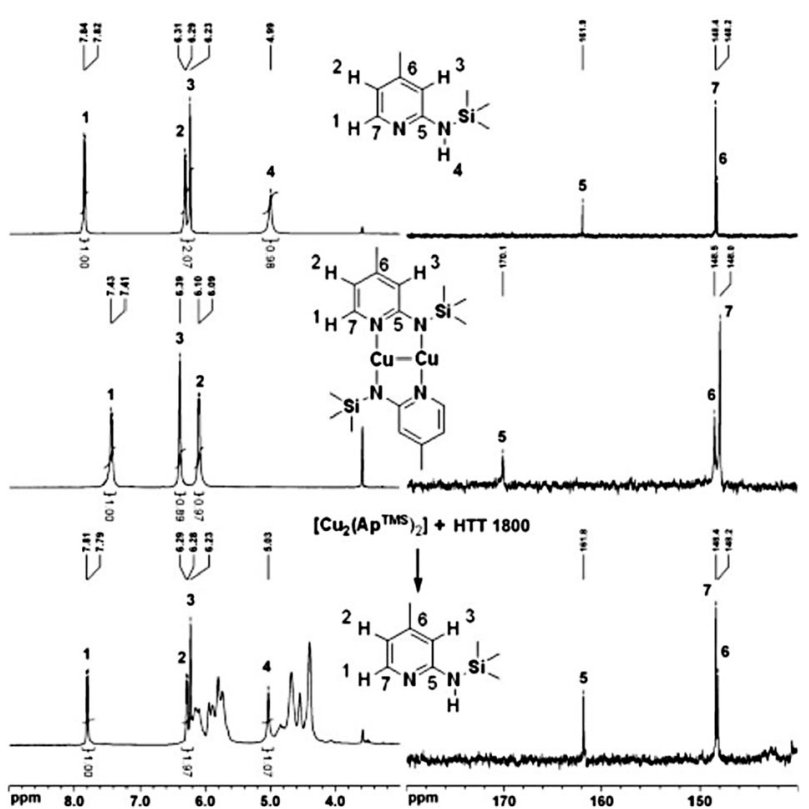

Fig. $16{ }^{1} \mathrm{H}$ (left) and ${ }^{13} \mathrm{C}$ NMR spectra (right) of $\mathrm{Ap}^{\mathrm{TMS}} \mathrm{H}$ (top), $\left[\mathrm{Cu}_{2} \mathrm{Ap}_{2}{ }^{\mathrm{TMS}}\right]$ (middle), and after its reaction with HTT1800 (bottom). (reproduced with permission from ref. 60. Copyright 2010 Wiley-VCH verlag GmbH \& Co. KGaA, Weinheim).

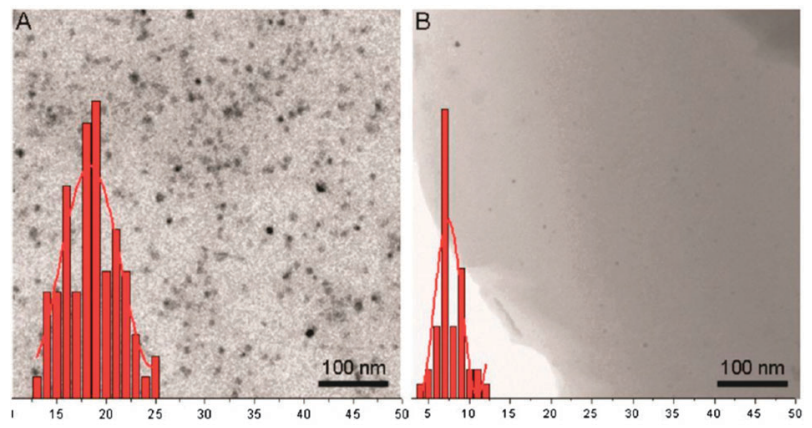

Fig. 17 TEM micrographs of $\mathrm{Cu} @ \mathrm{SiCN}: \quad$ (A) $\mathrm{Si} / \mathrm{Cu}=10$ (B) $\mathrm{Si} / \mathrm{Cu}=100$ including particle size distribution statistics.

Interestingly, a very different behaviour was found for palladium aminopyridinates (in comparison to copper) which generate intermetallic nanoparticles.

Simultaneous chemical modification of the polyorganosilazane HTT1800 as well as its cross-linking was achieved by the use of an aminopyridinato palladium complex at room temperature. ${ }^{64}$ Cross-linking takes place with an evolution of hydrogen supporting a dehydrocoupling mechanism in parallel to hydrosilylation, which increases the ceramic yield by the retention of carbon and nitrogen atoms (which otherwise are lost in the form of $\mathrm{CH}_{4}$ and $\mathrm{NH}_{3}$ ). The ceramic yield was found to be even higher than in the case of the pure PSZ, cross-linked by the addition of free radical initiators like DCP. Liberation of the ligand, as confirmed again by ${ }^{1} \mathrm{H}$ NMR spectroscopy, provides indirect evidence of the transfer of palladium to the nitrogen functions producing palladium modified PSZ. Pyrolysis at $1100{ }^{\circ} \mathrm{C}$ under nitrogen atmosphere provides $\mathrm{Pd}_{2} \mathrm{Si} @ \mathrm{SiCN}$. Powder X-ray diffraction studies confirmed the presence of the hexagonal $\mathrm{Pd}_{2} \mathrm{Si}$ phase in the amorphous SiCN matrix. 

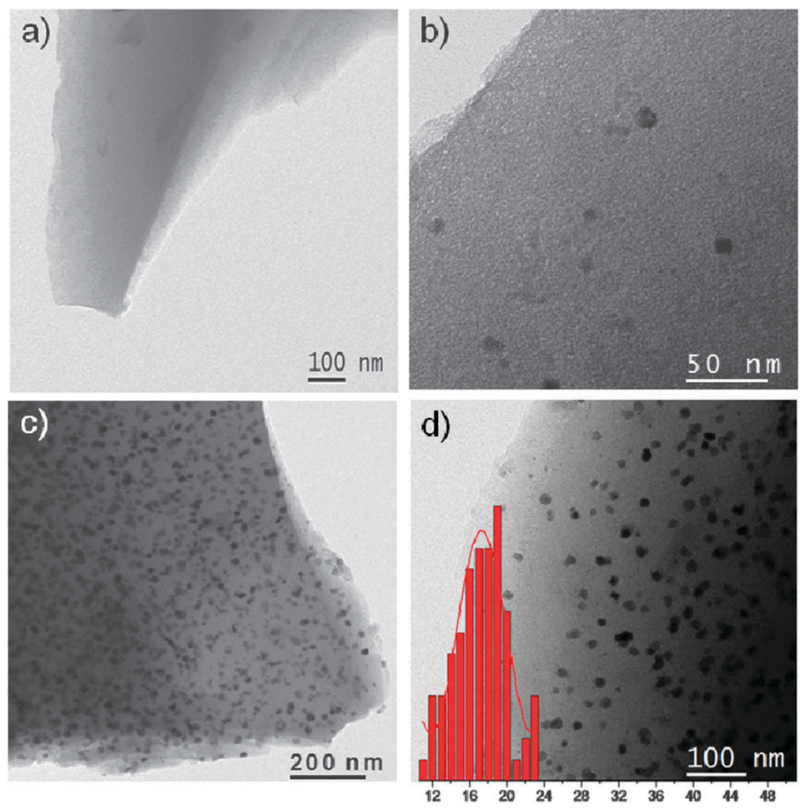

Fig. 18 TEM micrographs of ceramic materials. (a) SiCN ceramic without palladium loading does not show any particles; (b) lower loading of palladium $(0.2 \mathrm{wt} \%, \mathrm{Si} / \mathrm{Pd}$ ratio 1000$)$ decreases the density of particles keeping their size in the same regime; (c) $\mathrm{Pd}_{2} \mathrm{Si}$ particles uniformly distributed over the ceramic support $\mathrm{Si} / \mathrm{Pd}=20$ (8 wt \% Pd); (d) particle size distribution for the sample shown in (c) (reproduced after permission from ref. 64. Copyright 2011 Royal Society of Chemistry).

The size of the particles formed depends upon the nature of the solvent used in the cross-linking step. The amount of the palladium complex added seems not to affect the size of particles formed but does increase their population density (Fig. 18). For the catalytic applications of $\mathrm{Pd}_{2} \mathrm{Si} @ \mathrm{SiCN}$ see chapter 5.2.

The Wiesner group ${ }^{65}$ developed a highly innovative bottom-up approach to fabricate porous $\mathrm{SiCN}$ ceramics with integrated platinum nanoparticles. Structuring of the material was achieved through a combination of micromolding and multicomponent colloidal self-assembly. The coordination compound [(cod) $\left.\mathrm{PtMe}_{2}\right](\mathrm{COD}=1,5$ cyclooctadiene $)$ was used as a platinum precursor. Heat treatment $\left(1000{ }^{\circ} \mathrm{C}\right.$ under inert atmosphere) resulted in hierarchically structured porous ceramic material functionalized with Pt nanoparticles (Fig. 19).

In an attempt to couple the generation of metal nanoparticles and porosity within SiCN ceramics the chemical modification of HTT1800 with aminopyridinato complexes along with the addition of the sacrificial filler (polyethylene) was investigated. ${ }^{66}$

In a simultaneous process, both porosity (Fig. 20) and carbon nanotubes (CNTs) (Fig. 20c, Fig. 21) were generated. The thermal de-composition of the polyethylene leads not only to the formation of an open porosity, but also to an in situ reaction of its pyrolysis products with the metal nanoparticles to form the CNTs in the pores. Depending on the metal, carbon nanotubes as well as turbostratic carbon were formed in different amounts. During pyrolysis, gaseous hydrocarbons are formed whose decomposition results in the generation of CNTs via a chemical vapor deposition (CVD) process. Cobalt and iron were found to be more effective in the generation of nanotubes than the other metals employed.
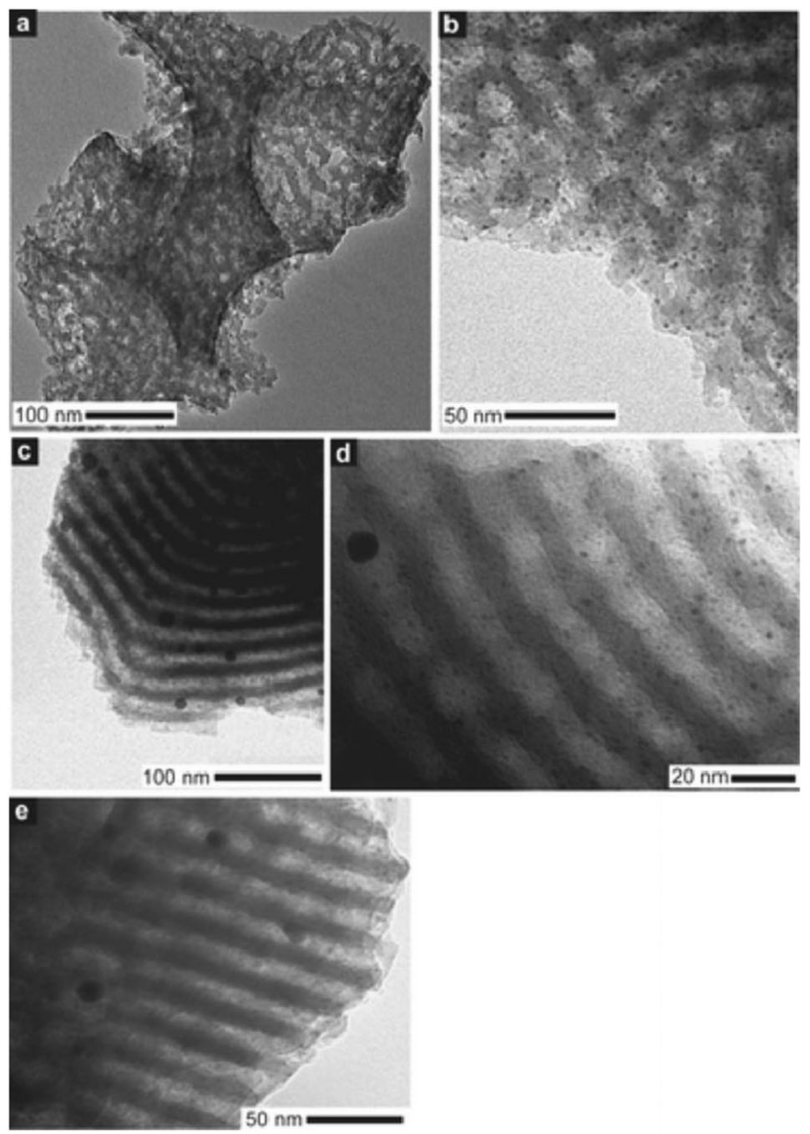

Fig. 19 (a, b) TEM micrographs showing the Pt nanoparticles homogeneously distributed throughout the material. (c, d) TEM micrographs of material post heat treated to $600{ }^{\circ} \mathrm{C}$ in air for $1 \mathrm{~min}$ and (e) for an additional $10 \mathrm{~h}$ (reproduced after permission from ref. 65. Copyright 2009 American Chemical Society).
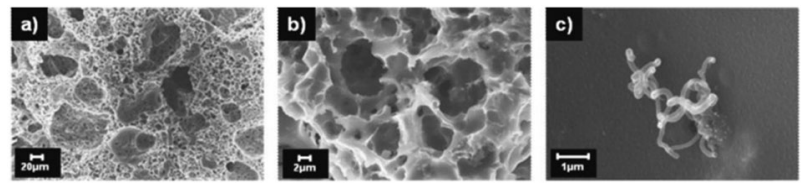

Fig. 20 (a-c) SEM micrographs of a $\mathrm{Au} @ \operatorname{SiCN}$ ceramic $\left(1000{ }^{\circ} \mathrm{C} / \mathrm{N}_{2}\right.$; $\mathrm{Au}: \mathrm{Si}=1: 50$ ) (reproduced after permission from ref. 66. Copyright 2011 Elsevier Ltd.).

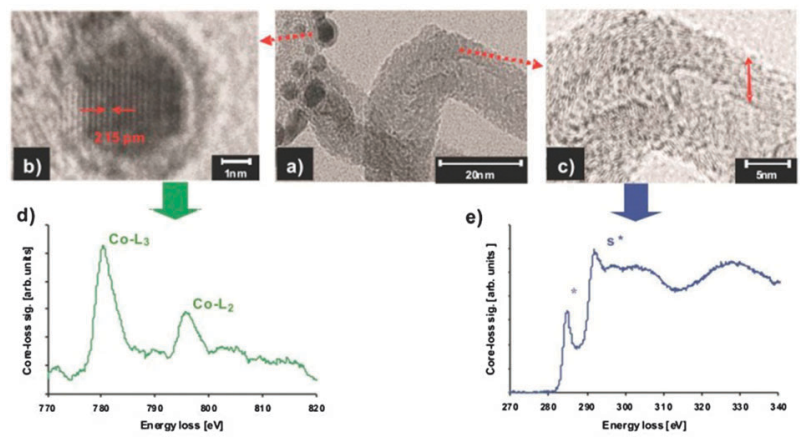

Fig. 21 TEM micrographs of a $\mathrm{Co} @ \mathrm{SiCN}$ ceramic $(\mathrm{Co}: \mathrm{Si}$ ratio = $1: 50$ ) (d) core-loss EELS of the metal particle (e) core-loss EELS of the carbon nanotube (reproduced after permission from ref. 66 . Copyright 2011 Elsevier Ltd.). 


\section{Applications}

\subsection{Magnetic applications}

Incorporating metals into non-oxide, polymer derived ceramics gives interesting magnetic properties to the ceramics depending upon the nature and size of nanosized species generated into the resulting ceramics. The crystallization of transition metals, metal oxides, carbides, nitrides and silicides leads to the magnetic properties of such composite materials. Ferromagnetism is the most commonly observed type of magnetism in these materials. Ferromagnetic materials are attracted by the applied magnetic field owing to the presence of unpaired electrons which align parallel to each other even after the applied field is completely removed. A ferromagnetic material can further be transformed into 'superpara-magnetic material' which occurs when ferromagnetic crystallites are smaller than $1-10 \mathrm{~nm}$. In sufficiently small sized nanoparticles, magnetization can randomly flip direction under the influence of temperature. Thus the materials behave like a paramagnetic material but the magnetic moment of the crystallites aligns with the external magnetic field. Above a specific temperature (Curie temperature $T_{\mathrm{c}}$ ) the parallel alignment of magnetic spins is completely disordered and the material becomes paramagnetic.

$\mathrm{SiCN}$ ceramics synthesized by the mixing of $\mathrm{Fe}_{3} \mathrm{O}_{4}$ powder with the polysilazane precursor ${ }^{44}$ showed lower saturation magnetization $\left(M_{\mathrm{s}}\right.$ : increase in the strength of the external magnetic field cannot increase the magnetization of the material further. A characteristic of the ferromagnetic materials) when pyrolyzed at $600{ }^{\circ} \mathrm{C}$ than the one pyrolyzed at $1000{ }^{\circ} \mathrm{C}$. This difference in magnetization can be explained by the lower magnetization of $\mathrm{Fe}_{3} \mathrm{O}_{4}$ species present at $600{ }^{\circ} \mathrm{C}$ than that of $\alpha$-Fe particles present at $1000{ }^{\circ} \mathrm{C}$. The mixing and ball milling of $\mathrm{Fe}$ powder with Ceraset ${ }^{\mathbb{R}}$ resulted in the crystallization of $\mathrm{Fe}_{3} \mathrm{Si}$ and the material showed a high saturation magnetization $\left(M_{\mathrm{s}}\right)$ of $57 \mathrm{emu} \mathrm{g}^{-1}$. The formation of ferromagnetic phase was attributed to the formation of $\mathrm{Fe}_{3} \mathrm{Si}^{48}$

The formation of metal silicides in $\mathrm{SiCN}$ ceramics synthesized by the mixing of metal powders with Ceraset ${ }^{\mathbb{R}}$ affects the magnetic properties which were studied at both $-196{ }^{\circ} \mathrm{C}$ and room temperature. The ceramics containing iron silicide $\left(\mathrm{Fe}_{3} \mathrm{Si}\right)$ particles show soft magnetism at both temperatures and can be easily saturated with the magnetization vector. The composites filled with Co powder show better magnetic properties than those containing $\mathrm{Mn}$ or $\mathrm{Ni}$ powder. This could be attributed to the formation of $\mathrm{Mn}$ and $\mathrm{Ni}$ silicides by the metal-matrix interactions which are absent in the case of Co. ${ }^{45,46}$

The Fe@SiCN ceramic synthesized by the pyrolysis of iron containing polysilazane at $500-900{ }^{\circ} \mathrm{C}$ under nitrogen stream resulted in the formation of iron nanoparticles and an increase in $M_{\mathrm{s}}$ was observed with an increase of the pyrolysis temperature. When pyrolyzed under ammonia, saturation magnetization of the materials increases up to $700{ }^{\circ} \mathrm{C}$ and then decreases. This behaviour may be explained by the change of major magnetic crystallites present at different pyrolysis temperatures $\left(\mathrm{Fe}_{3} \mathrm{~N}\right.$ at 500 and $600{ }^{\circ} \mathrm{C} ; \mathrm{Fe}_{4} \mathrm{~N}$ and $\mathrm{Fe}$ at $700{ }^{\circ} \mathrm{C} ; \mathrm{Fe}$ at $\left.800{ }^{\circ} \mathrm{C}\right) .{ }^{56}$

Ceramics synthesized by the pyrolysis of ferrocene based organosilicon polymers show superparamagnetism or ferromagnetism depending upon the pyrolysis temperature which in turn decides the size of iron nanoparticles formed. ${ }^{14,52}$
At lower temperatures smaller size particles are formed which give superparamagnetic materials. ${ }^{13,28}$ At higher temperatures iron clusters become larger in size giving ferromagnetic properties to the material. ${ }^{15,27} \mathrm{~A}$ similar behaviour was observed in the ceramics containing alloy particles $(\mathrm{Co} / \mathrm{Fe}),{ }^{30,33}$ metal silicide particles $^{16,21,35}$ and ceramic nanowires ${ }^{40}$ or thin films containing iron. ${ }^{34}$ The superparamagnetic and ferromagnetic properties of the materials can also be tuned in terms of the composition of metallopolymer precursor which in turn controls the nature of crystallites formed within the ceramics. ${ }^{54}$

\subsection{Heterogeneous catalysis}

The robust nature of a ceramic makes it an ideal candidate for a catalytic support. The thermal robustness might be suitable for high temperature application like dry reforming, the conversion of methane and $\mathrm{CO}_{2}$ to 'syn-gas' $\left(\mathrm{CO}\right.$ and $\left.\mathrm{H}_{2}\right)$. It is also of advantage if the catalysis itself is done at lower temperature, but the catalyst reactivation, like removal of coking and other impurities, may involve high temperature steps. Secondly, a support like non-oxide $\mathrm{SiC}$ and $\mathrm{SiCN}$ ceramics differs from an oxide support in terms of polarity and acidic properties. Thirdly, non-oxide ceramics are comparatively inert and can be applied for solution phase catalysis under chemically harsh conditions, like high $\mathrm{pH}$ values for instance, under which oxide supports may simply dissolve. The shortage of petroleum and the resulting price increase of this fossil carbon source as well as environmental concerns require more use of alternative, preferentially, renewable resources. The different catalytic chemistry related to this change may require solution phase catalysts, which are chemically rather inert. The use of nonoxide ceramics as catalytic support materials is quite rare and only a few reports could be found in the literature.

$\mathrm{Cu} @ \mathrm{SiCN}$ was studied in the catalytic oxidation of alkanes (cyclooctane) using air as an oxidant. ${ }^{60}$ Oxidation of nonactivated alkanes is very challenging especially if the cheap oxidant air is used. Alkanes are rather inert and thermodynamically preferred total oxidation is highly competitive. The selective formation of cyclooctanone (monooxygenated product) was observed, which increase with a higher copper content of the used ceramics (see Fig. 22). The catalysts did not show any loss of activity up to four consequent catalytic runs. Copper is also regarded as a catalytically interesting metal due to its low price.

Furthermore, the oxidation of methane by $\mathrm{O}_{2}$ was investigated using platinum nanoparticles supported by a hierarchically structured porous $\mathrm{SiCN}$ ceramic. ${ }^{65}$ Thermogravimetric analysis (TGA) did not show any substantial change in the weight of pyrolysed structure under oxygen atmosphere at $600{ }^{\circ} \mathrm{C}$. Moreover, postpyrolysis order retention as verified by small angle X-ray spectroscopy (SAXS) confirmed the stability of the catalyst in an oxidizing environment. The size of the particles, however, increased from 1-2 $\mathrm{nm}$ to $10 \mathrm{~nm}$ after heat treatment at $600{ }^{\circ} \mathrm{C}$. The carbon dioxide was the only product detected suggesting the total oxidation of methane under experimental conditions.

The catalytic total oxidation of methane was also investigated using $\mathrm{Pt} / \mathrm{CeO}_{2} / \mathrm{SiC}$ composites. ${ }^{37}$ The catalysts showed good catalytic activity and stability towards methane oxidation which was attributed to the presence of nanosized 


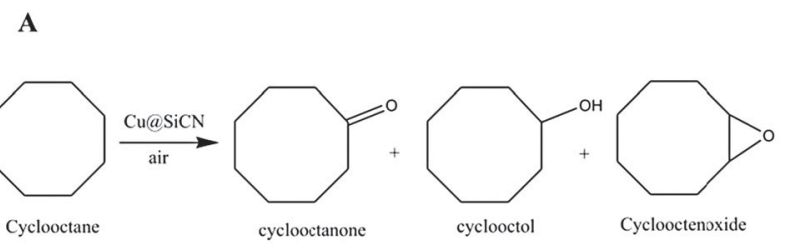

B

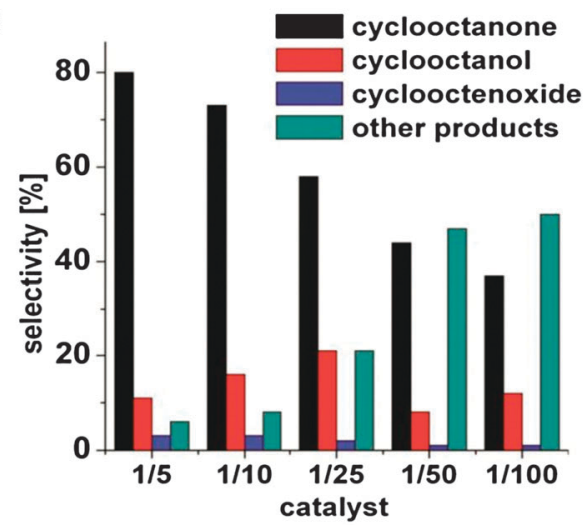

Fig. 22 Scheme showing the formation of different products obtained by the oxidation of cyclooctane using $\mathrm{Cu} @ \mathrm{SiCN}$ as catalyst (A). Selectivities [\%] of different catalysts (B). The copper to silicon ratios vary from $1: 5$ to $1: 100$ (reproduced from ref. 60 after permission. Copyright 2010 Wiley-VCH Verlag GmbH \& Co. KGaA, Weinheim).

platinum and ceria species. The catalytic activity decreased both with the decrease in specific surface area and the amount of ceria contained by the catalysts.

Palladium silicide containing SiCN catalysts $\left(\mathrm{Pd}_{2} \mathrm{Si} @ \mathrm{SiCN}\right)$ were used for the selective hydrogenation of aromatic ketones. ${ }^{64}$ The selectivity of the reaction towards alcoholic products remained very high and did not change with the amount of palladium content or with the amount of catalysts added. The conversion increased both with the increase in the reaction temperature and the amount of catalyst used, while it decreased with the increase in alkyl chain length and its branching at $\alpha$-carbon. The catalysts manifested appreciable reusability and no loss in the activity of the catalysts was observed up to six consecutive catalyst runs (Fig. 23).

\subsection{Other applications}

Some M@SiCN ceramics, containing copper or silver nanoparticles, could be used in medical applications, as they can act as fungicides $(\mathrm{Cu})$ or bactericides $(\mathrm{Ag})$. So, for example, some silver modified PDCs have been tested in detail for their antibacterial potentials and show strong activities against some of the bacterial species (Escherichia coli and Staphylococcus aureus). ${ }^{50}$

\section{Conclusions and outlook}

The relatively young materials based on polymer derived ceramics should be a promising technology for different challenging applications in the future. This article gives an overview of the rather rare examples of non-oxide PDCs modified by late transition metals. The different possible synthesis strategies for the desired metal modification of

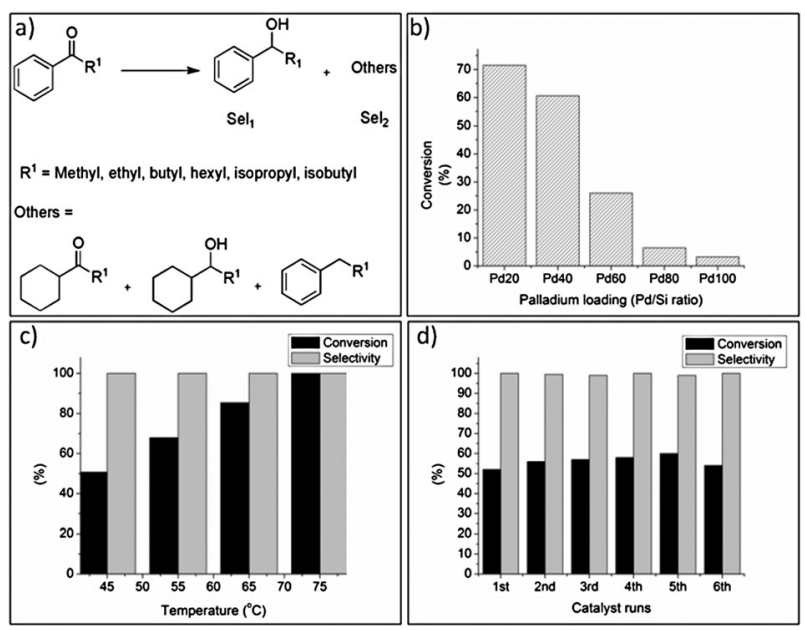

Fig. 23 (a) Schematic representation of catalytic hydrogenation of ketones to different products; (b) hydrogenation of acetophenone ( $2 \mathrm{mmol}$ ) with $60 \mathrm{mg}$ of catalyst at $75^{\circ} \mathrm{C}$ under 20 bar hydrogen for 24 hours. The conversion decreases with decrease in the amount of palladium contained by the ceramics; (c) hydrogenation of acetophenone ( $2 \mathrm{mmol}$ ) using Pd20 (120 mg) under 20 bar hydrogen pressure for 24 hours. The conversion increases with temperature keeping the selectivity constant; (d) hydrogenation of acetophenone ( $2 \mathrm{mmol})$ with the catalyst Pd20 $(60 \mathrm{mg})$ under 20 bar hydrogen pressure at $75{ }^{\circ} \mathrm{C}$ for 24 hours. The figure shows reusability of the catalyst up to six catalyst runs (reproduced with permission from ref. 64. Copyright 2011 The Royal Society of Chemistry).

$\mathrm{SiC}$ and $\mathrm{SiCN}$ ceramics are the simple addition of metal (oxide) powders to the precursors (i), the development of well defined metallopolymers (ii), and the rather new way of using metal coordination compounds for the metal transfer reactions (iii).

The first mentioned way is limited by the size of the used metal (oxide) powders, while in the case of (ii) and (iii) a bottom-up approach, coming from the atomic scale, is realized. This offers, at least theoretically, the possibility to tune the size of the formed metal nanoparticles inside the derived PDCs.

In content with metallopolymers a lot of work dealing with ferrocene containing systems was published, while in the case of the modification by coordination compounds, the use of amino-pyridinato complexes is very actual. Up to now it was possible to synthesize and characterize several chemically modified precursors using a series of specially developed, partially new aminopyridinato complexes, which act as metal transfer reagents towards the $\mathrm{N}$-functionalities of polysilazanes. One important point along this way, was getting analytical evidence exactly for these metal-nitrogen bonds, which we were able to receive from NMR spectroscopy, at least in parts. This new technique for highly disperse loading of active particles onto ceramic structures by a direct chemical bond between the metal and precursor has been successfully demonstrated and the considerable advantages gained over other, conventional processes, could be verified. As these coordination compounds are available for nearly all transition elements, the corresponding modifications should be possible.

For all the manufactured metal containing non-oxide ceramics numerous analytical techniques were used to get evidence for the 
present morphologies, structures and compositions of both ceramic materials and metal (nano) particles.

Some examples of potential applications of the iron modified polymer derived ceramics, especially in the use of their magnetic properties, are given. The use of $\mathrm{M} @ \mathrm{SiC} / \mathrm{SiCN}$ systems for different catalytic transformations is described.

As ceramics will have increasing applications as membranes, filter materials or catalysts in future, also the materials based on precursor derived ceramics should be further developed in these fields. The metal modified polymer systems, which can be thermally converted into the ceramic materials, are promising candidates therefore. In future, new combinations of metal/precursor should be tested to enable the development of "tailored" precursor ceramics for more and other applications in catalysis, filter technique or also for example the fields of energy conservation (e.g. hydrogen storage), environmental protection or fuel cells. Clearly, therefore much additional development work is necessary.

\section{Acknowledgements}

Financial support from the Deutsche Forschungsgemeinschaft (DFG) in context of the SPP 1181: "Nanoscaled Inorganic Materials by Molecular Design: New Materials for Advanced Technologies" is gratefully acknowledged.

\section{Notes and references}

1 Polymer derived Ceramics-From Nano-Structure to Applications, ed. P. Colombo, R. Riedel, G. D. Soraru and H.-J. Kleebe, DEStech Publications, Pennsylvania, 2010.

2 R. Riedel, G. Mera, R. Hauser and A. Klonczynski, J. Ceram. Soc. Jpn., 2006, 114, 425-444.

3 P. Miele, S. Bernard, C. Cornu and B. Toury, Recent developments in polymer-derived ceramic fibers (PDCFs): preparation, properties and applications $-A$ review, Soft Mater., Taylor \& Francis, Inc., 2007, vol. 4(2-4), pp. 249-286.

$4 \mathrm{P}$. Miele and S. Bernard, Boron- and nitrogen-containing polymers for advanced materials, Macromolecules Containing Metal and Metal-Like Elements, 8 (boron-containing polymers), John Wiley \& Sons, Inc., 2007, pp. 103-120.

$5 \mathrm{H}$. Schmidt, $\mathrm{Si}-(B-) C-N$ ceramics derived from preceramic polymers: stability and nano-composite formation. Soft Mater., Taylor \& Francis, Inc., 2007, vol. 4(2-4), pp. 143-164.

6 S. Yajima, T. Shishido and H. Kayano, Nature, 1976, 264, 237-238.

7 R. J. P. Corriu, P. Gerbier, C. Guerin and B. Henner, J. Mater. Chem., 2000, 10, 2173-2182.

8 D. Seyferth, H. Lang, C. A. Sobon, J. Borm, H. J. Tracy and N. Bryson, J. Inorg. Organomet. Polym. Mater., 1992, 2, 59-77.

9 G. R. Whittell and I. Manners, Adv. Mater., 2007, 19, 3439-3468.

10 B.-Z. Tang, R. Petersen, D. A. Foucher, A. Lough, N. Coombs, R. Sodhib and I. Manners, J. Chem. Soc., Chem. Commun., 1993, 523-525.

11 R. Petersen, D. A. Foucher, B.-Z. Tang, A. Laugh, N. P. Raju, J. E. Greedan and I. Manners, Chem. Mater., 1995, 7, 2045-2053.

12 M. J. MacLachlan, P. Aroca, N. Coombs, I. Manners and G. A. Ozin, Adv. Mater., 1998, 10, 144-149.

13 M. J. MacLachlan, M. Ginzburg, N. Coombs, N. P. Raju, J. E. Greedan, G. A. Ozin and I. Manners, J. Am. Chem. Soc., 2000, 122, 3878-3891.

14 M. J. MacLachlan, M. Ginzburg, N. Coombs, T. W. Coyle, N. P. Raju, J. E. Greeden, G. A. Ozin and I. Manners, Science, 2000, 287, 1460-1463.

15 M. Ginzburg, M. J. MacLachlan, S. M. Yang, N. Coombs, T. W. Coyle, N. P. Raju, J. E. Greedan, R. H. Herber, G. A. Ozin and I. Manners, J. Am. Chem. Soc., 2002, 124, 2625-2639.
16 Q. Sun, J. W. Y. Lam, K. Xu, H. Xu, J. A. K. Cha, P. C. L. Wong, G. Wen, X. Zhang, X. Jing, F. Wang and B. Z. Tang, Chem. Mater., 2000, 12, 2617-2624.

17 M. G. Margau, S. F. Bidoz, N. Coombs, G. A. Ozin and I. Manners, Chem. Commun., 2002, 3022-3023.

18 K. Liu, S. F. Bidoz, G. A. Ozin and I. Manners, Chem. Mater., 2009, 21, 1781-1783.

19 J. Galloro, M. Ginzburg, H. Miguez, S. M. Yang, N. Coombs, A. S. Stefat, J. E. Greedan, I. Manners and G. A. Ozin, Adv. Funct. Mater., 2002, 12, 382-388.

20 Y. Yu, L. An, Y. Chen and D. Yang, J. Am. Ceram. Soc., 2010, 93, 3324-3329.

21 V. A. Du, A. Sidorenko, O. Bethge, S. Paschan, E. Bertagnolli and U. Schubert, J. Mater. Chem., 2011, 21, 12232-12238.

22 J. Massey, K. N. Power, I. Manners and M. A. Winnik, J. Am. Chem. Soc., 1998, 120, 9533-9540.

23 J. A. Massey, M. A. Winnik and I. Manners, J. Am. Chem. Soc., 2001, 123, 3147-3148.

24 X.-S. Wang, A. Arsenault, G. A. Ozin, M. A. Winnik and I. Manners, J. Am. Chem. Soc., 2003, 125, 12686-12687.

25 L. Cao, J. A. Massey, M. A. Winnik, I. Manners, S. Riethmüller, F. Banhart, J. P. Spatz and M. Möller, Adv. Funct. Mater., 2003, 13, 271-276.

26 D. A. Rider, K. Liu, J.-C. Eloi, L. Vanderark, L. Yang, J.-Y. Wang, D. Grozea, Z.-H. Lu, T. P. Russell and I. Manners, ACS Nano, 2008, 2, 263-270.

27 K. Kulbaba, A. Cheng, A. Bartole, S. Greenberg, R. Resendes, N. Coombs, A. S. Sefat, J. E. Greedan, H. D. A. Stöver, G. A. Ozin and I. Manners, J. Am. Chem. Soc., 2002, 124, 12522-12534.

28 K. Temple, K. Kulbaba, K. N. P. Billard, I. Manners, K. A. Leach, T. Xu, T. P. Russell and C. J. Hawker, Adv. Mater., 2003, 15, 297-300.

29 A. Berenbaum, M. G. Margau, N. Coombs, A. J. Lough, A. S. Sefat, J. E. Greedan, G. A. Ozin and I. Manners, Adv. Mater., $2003, \mathbf{1 5}, 51-55$.

30 S. B. Clendenning, S. F. Bidoz, A. Pietrangelo, G. Yang, S. Han, P. M. Brodersen, C. M. Yip, Z.-H. Lu, G. A. Ozin and I. Manners, J. Mater. Chem., 2004, 14, 1686-1690.

31 A. Y. Cheng, S. B. Clendenning, G. Yang, Z.-H. Lu, C. M. Yip and I. Manners, Chem. Commun., 2004, 780-781.

32 S. B. Clendenning, S. Han, N. Coombs, C. Paquet, M. S. Rayat, D. Grozea, P. M. Brodersen, R. N. S. Sodhi, C. M. Yip, Z.-H. Lu and I. Manners, Adv. Mater., 2004, 16, 291-296.

33 K. Liu, S. B. Clendenning, L. Friebe, W. Y. Chan, X. Zhu, M. R. Freeman, G. C. Yang, C. M. Yip, D. Grozea, Z.-H. Lu and I. Manners, Chem. Mater., 2006, 18, 2591-2601.

34 K. R. Thomas, A. Ionescu, J. Gwyther, I. Manners, C. H. W. Barnes, U. Steiner and E. Sivaniah, J. Appl. Phys., 2011, 109, 073904

35 L. Friebe, K. Liu, B. Obermeier, S. Petrov, P. Dube and I. Manners, Chem. Mater., 2007, 19, 2630-2640.

36 R. J. P. Corriu, N. Devylder, C. Guerin, B. Henner and A. Jean, J. Organomet. Chem., 1996, 509, 249-257.

37 E. Kockrick, R. Frind, M. Rose, U. Petasch, W. Boelhlmann, D. Gieger, M. Herrmann and S. Kaskel, J. Mater. Chem., 2009, 19, $1543-1553$.

38 D. Seyferth, H. Lang, C. A. Sobon, J. Borm, H. J. Tracy and N. Bryson, J. Inorg. Organomet. Polym., 1992, 2, 59-77.

39 D. Seyferth, C. A. Sobon and J. Borm, New J. Chem., 1990, 14, 545-547.

40 R. Mishra, R. K. Tiwari and A. K. Saxena, J. Inorg. Organomet. Polym. Mater., 2009, 19, 223-227.

41 X. Chen, Z. Su, L. Zhang, M. Tang, Y. Yu, L. Zhang and L. Chen, J. Am. Ceram. Soc., 2010, 93, 89-95.

42 C. Vakifahmetoglu, E. Pippel, J. Woltersdorf and P. Colombo, J. Am. Ceram. Soc., 2010, 93, 959-968.

43 C. Vakifahmetoglu, P. Colombo, S. M. Carturan, E. Pippel and J. Wotersdorf, J. Am. Ceram. Soc., 2010, 93, 3709-3719.

44 A. Saha, S. R. Shah and R. Raj, J. Mater. Res., 2003, 18, $2549-2551$.

45 X. Yan, X. Cheng, G. Han, R. Hauser and R. Riedel, Key Eng. Mater., 2007, 353-358, 1485-1488.

46 X. Yan, X. Cheng, C. Li, R. Hauser and R. Riedel, Mater. Sci. Forum, 2007, 546-549, 2269-2272. 
47 H.-Y. Ryu and R. Raj, J. Am. Ceram. Soc., 2007, 90, 295-297.

48 R. Hauser, A. Francis, R. Theismann and R. Riedel, J. Mater. Sci., 2008, 43, 2042-2049.

49 A. Francis, E. Ionescu, C. Fasel and R. Riedel, Inorg. Chem., 2009, 48, 10078-10083.

50 V. Bakumov, K. Gueinzius, C. Hermann, M. Schwarz and E. Kroke, J. Eur. Ceram. Soc., 2007, 27, 3287-3292.

51 X. Hu, Y. Li and C. Xu, J. Appl. Polym. Sci., 2010, 118, 3384-3390.

52 J. Li, Z. Zhang, Z. Zheng, L. Guo, G. Xu and Z. Xie, J. Appl. Polym. Sci., 2007, 105, 1786-1792.

53 A. Dumitru, I. Stamatin, A. Morozan, C. Mirea and V. Ciupina, Mater. Sci. Eng., C, 2007, 27, 1331-1337.

54 A. Dumitru, A. Morozan, C. Mirea, D. Mihaiescu, C. Panaiotu, V. Ciupina and I. Stamatin, Combust. Sci. Technol., 2005, 65, 713-717.

55 A. Dumitru, V. Ciupina, I. Stamatin, G. Prodan, A. Morozan and C. Mirea, J. Optoelectron. Adv. Mater., 2006, 8, 50-54.

56 Y. Li, Z. Zheng, C. Reng, Z. Zhang, W. Gao, S. Yang and Z. Xie, Appl. Organomet. Chem., 2003, 17, 120-126.

57 J. H. Park, K. H. Park and D. P. Kim, J. Ind. Eng. Chem., 2007, 13, $27-32$.
58 S. I. Andronenko, I. Stiharu, D. Menard, C. Lacroix and S. K. Misra, Appl. Magn. Reson., 2010, 38, 385-402.

59 M. S. Bazarjani, H.-J. Kleebe, M. M. Müller, C. Fasel, M. B. Yazdi, A. Gurlo and R. Riedel, Chem. Mater., 2011, 23, $4112-4123$.

60 G. Glatz, T. Schmalz, T. Kraus, F. Haarmann, G. Motz and R. Kempe, Chem.-Eur. J., 2010, 16, 4231-4238.

61 For a review article on aminopyridinato ligands see: R. Kempe, Eur. J. Inorg. Chem., 2003, 791-803.

62 For discussion of the binding modes see: S. Deeken, G. Motz and R. Kempe, Z. Anorg. Allg. Chem., 2007, 633, 320-325.

63 For the general applicability of these ligands please see: G. Glatz, G. Motz and R. Kempe, Z. Anorg. Allg. Chem., 2008, 634, $2897-2902$.

64 M. Zaheer, G. Motz and R. Kempe, J. Mater. Chem., 2011, 21, 18825-18831.

65 M. Kamperman, A. Burns, R. Weissgraeber, N. V. Vegten, S. C. Warren, S. M. Gruner, A. Baiker and U. Wiesner, Nano Lett., 2009, 9, 2756-2762.

66 T. Schmalz, T. Kraus, M. Guenthner, C. Liebscher, U. Glatzel, R. Kempe and G. Motz, Carbon, 2011, 49, 3065-3072. 